The first original version of this manuscript has been submitted on April 12 2021 for consideration in the Agricultural Water Management. Please note the manuscript is under review and it has not been accepted for publication. Subsequent versions of this manuscript may have slightly different contents. Please feel free to contact the corresponding author; we welcome feedback. 


\title{
Towards an operational irrigation management system for Sweden with a water-food-energy nexus perspective
}

\author{
P.E. Campana ${ }^{1}$, P. Lastanao ${ }^{1}$, S. Zainali ${ }^{1}$, J. Zhang ${ }^{2}$, T. Landelius ${ }^{3}$, F. Melton ${ }^{4,5}$ \\ 1 Mälardalen University, Department for Environmental Engineering and Energy Processes, Västerås SE 72123, Sweden \\ 2 Uppsala University, Department of Earth Sciences, Uppsala SE 75236, Sweden \\ 3 Swedish Meteorological and Hydrological Institute, Norrköping SE 60176, Sweden \\ 4 NASA Ames Research Center Cooperative for Research in Earth Science and Technology (NASA ARC-CREST), \\ Moffett Field CA 94035, USA \\ 5 California State University Monterey Bay, Seaside CA 93955, USA
}

\begin{abstract}
The 2018 drought in Sweden has triggered questions about climate adaptation and mitigation measures, especially in the agricultural sector, which suffered the most. This study applies a water-food-energy nexus modelling framework to evaluate drought impacts on irrigation and agriculture in Sweden using 2018 and 2019 as case studies. A previous water-food-energy nexus model was updated to facilitate an investigation of the benefits of data-driven irrigation scheduling as compared to existing irrigation guidelines. Moreover, the benefits of assimilating earth observation data in the crop model have been explored. The assimilation of leaf area index data from the Copernicus Global Land Service significantly improve the crop yield estimation as compared to default crop model parameters. The results show that the irrigation water productivities of the proposed model are measurably improved compared to conventional irrigation guidelines both in 2018 and in 2019. This is mostly due to the advantage of the proposed model in providing $E T_{c}$-driven guidelines by using spatially-explicit data generated by mesoscale models from the Swedish Meteorological and Hydrological Institute. During a normal year, the proposed irrigation management system leads to significant water savings as compared to conventional irrigation guidelines. The modelling results show that temperature stress during the 2018 drought played a key role in the crop yield reduction, with yield reductions of up to $35 \%$. In the context of the water-food-energy nexus, this motivates the implementation of new technologies to reduce water and temperature stress to mitigate likely negative effects of climate change. A visualization platform is developed using an open-source package for Google Earth ${ }^{\circledR}$ to help farmers and water and energy management agencies to better understand the connections between water and energy use and food production. This can be significant, especially during the occurrence of extreme events, but also to adapt to the negative effects of climate changes.
\end{abstract}

Keywords: water-food-energy nexus, drought, irrigation, data visualization.

\section{Introduction}

In 2018, Sweden experienced an unprecedented drought that severely affected the agricultural, water and energy sectors. During the period from June-July, some regions experienced a significant reduction in precipitation as compared to a normal year. Krikken et al. (2019) showed a precipitation anomaly for July 2018 ranging from $0 \mathrm{~mm}$ to $-100 \mathrm{~mm}$ as compared to 1981-2010 climatology. In July 2018, some locations, such as Kastlösa on Öland and Komstorp in Blekinge did not receive any precipitation while others such as Varberg and Öland's southern cape received 0.2 and $0.8 \mathrm{~mm}$, respectively (SMHI, 2020a). This caused a drastic reduction in crop yields, including key crops such as wheat, potatoes and other 
forage crops. The lack of forage crops negatively affected the dairy farmers and related industry. Analysis of the Standardised Precipitation-Evapotranspiration (SPEI) Index for the period from 1950 2020 indicates that 2018 was one of the worst droughts for Swedish farmers in more than 50 years (SPEI Global Drought Monitor, 2020). As a result, farmers had to start irrigating or installing irrigation systems. However, the scarcity of rainfall also severely affected the available water resources for agricultural production. Some counties, such as Skåne, issued restrictions on irrigation to preserve the scarce water resources, adding further stress to the farmers, especially those who had water-intensive crops, such as vegetables and potatoes (The Local, 2020). Compared to southern European countries such as Italy or Spain, where irrigation is a well-established practice, Swedish farmers generally lack adequate means and incentives to determine water use requirements for crops, schedule irrigation applications to match crop water requirements, evaluate the response of crop yields to different water management practices, and evaluate current on-farm water-efficiency levels. The combination of these factors led to the worst crop harvest since the 1950s for Sweden (Bioenergy International, 2020). The extreme drought also affected the energy sector. Higher volumes of water pumped for irrigation required higher electricity demand in the agricultural sector. Low precipitation levels affected hydropower generation due to low refilling volumes. The state-owned power company Vattenfall AB closed the 900 MW number 2 nuclear reactor at its Ringhals power plant since the high water required for the cooling process reached temperatures that could threaten the safety and function of the reactor (Renew Economy, 2020). This acute drought event in Sweden clearly highlighted the water-food-energy (WFE) nexus interrelationships and how those can be exacerbated during extreme events. Moreover, SMHI climate change scenarios predict that the annual mean temperature in Sweden will grow steadily from present until the year 2100 and beyond (Belusic et al., 2019). The precipitation patterns from climate models show high variability indicating that drought events and heat waves will likely happen more frequently, with socio-economic consequences in several sectors. As highlighted by Belusic et al. (2019), studies on drought and drought effects on water balance calculations in Scandinavia are limited. Sweden needs to account for increasing drought frequency and severity as part of ongoing planning efforts to mitigate the potential effects of climate change and extreme weather phenomena. In 2018, the Swedish Government presented a national crisis package valued at more than 1.2 billion SEK (1 $\mathrm{SEK} \approx 0.1$ USD), primarily to cover the fodder shortage and other loss of income that farmers experienced due to the drought. 760 million SEK were invested in 2019 to develop measures to alleviate the situation for the drought-affected agricultural sector (Government Offices of Sweden, 2020). Recently, Grusson et al. (2021) analyzed the impacts of climate change on the Swedish agriculture highlighting the increasing need for irrigation, especially during the beginning of the season due to a higher probability of dry springs. The SMHI provides a water-shortage risk service through an overview of groundwater levels, surface water levels, and statistical summaries of precipitation amounts. However, this service does not incorporate any dynamic satellite information regarding soil moisture and vegetation characteristics. Currently, only general irrigation guidelines, based on the PenmanMonteith equation (Allen et al., 1998) are provided. In addition, existing guidelines sometimes suggest different values. For instance, Bergström and Barkefors (2004) suggested irrigating potatoes with 100 $\mathrm{mm} / \mathrm{season}$ on average (maximum $200 \mathrm{~mm} / \mathrm{season}$ ). The Swedish Board of Agriculture (2007) mentioned that water requirements for potatoes should be between 300 and $350 \mathrm{~mm}$, assuming average precipitation during the same period between 170 and $250 \mathrm{~mm}$. The report from the Swedish Board of Agriculture (2007) also provided static guidelines for the irrigation of potatoes for different locations, e.g., Visby $\left(57.6348^{\circ} \mathrm{N}, 18.2948^{\circ} \mathrm{E}\right)$ with $130 \mathrm{~mm} /$ season recommended, and Umeå $\left(63.8258^{\circ} \mathrm{N}\right.$, $20.2630^{\circ}$ E) with $75 \mathrm{~mm} /$ season recommended. No irrigation management services are provided in Sweden unlike countries or regions that historically have been more prone to drought. In addition, the input data for irrigation as well as for nutrient management depends on spatio-temporal data such as climatological data and soil types, and this heterogeneity requires spatially explicit information to 
produce accurate guidelines. For this reason, researchers and institutions have been active in developing decision support systems based on simulation and optimization models, or satellite data observations, or hybrid approaches to provide guidelines on optimal irrigation and nutrient applications and thus inform smart farming management. The NASA Satellite Irrigation Management Support (SIMS) system (Melton et al., 2012; Pereira et al., 2020) integrates Earth observation data from Landsat and MODIS with meteorological observations to generate daily maps of evapotranspiration (ET) and 8-day map of crop coefficients for millions of hectares of farmland in the western United States (US). OpenET (OpenET, 2021) has implemented six satellite-based ET models on the Google Earth Engine platform (Gorelick et al., 2017) to make daily, monthly and annual ET data for the western US easily available at field scales (30m x 30m per pixel) via a web-based UI and application programming interface (API).

The aim of this study is to investigate the effects of implementing a gridded WFE irrigation management system for Sweden by using the spatially explicit climatic data generated by SMHI. Specific objectives of this study are to:

- further develop the model presented in Zhang et al. (2018) for Nebraska and in Campana et al. (2018) for Sweden by implementing the Penman-Monteith equation for the calculation of reference evapotranspiration, and related validation using remote sensing data and tower flux data;

- analyze the irrigation water productivity of existing irrigation guidelines in Sweden and compare the results with the guidelines provided by the developed model;

- analyze water-food-energy nexus aspects related to irrigation systems in Sweden;

- develop the model interface to create a demonstration system for a future operational service, primarily for farmers interested in crop conditions and irrigation guidelines, but also for energy and water management related agencies.

Although the model presented in this study is applied to Sweden using gridded data generated by two mesoscale models (Strång (2020) and Mesan (SMHI, 2020b)) from the SMHI, it has general validity and can be extended to other regions using different gridded products for climatological variables.

The paper is organized as follows: the problem statement and the objective of this study are introduced in Section 1; a literature review of water-food-energy nexus models and irrigation management systems is provided in section 2; data and methods are presented in section 3; the main results of this study (i.e., model validation, irrigation water productivity for three irrigation guidelines, and water-food energy nexus relationships in the irrigation sector, and visualization) are presented in Section 4; and, the conclusions of this study are summarized in section 5 .

\section{Literature review}

\subsection{Water-food-energy nexus models}

The concept of water-food-energy (WFE) nexus was introduced during the 2008 World economic forum to discuss the important interlinkages among the water, food, and energy sectors highlighted by the global food security crisis 2008 (Dominic, 2011). The WFE nexus approach ensures the identification and quantification of the synergies among sectors, supports the sustainable management of natural resources data and tools for decision-makers (Lawford, 2019), promotes ecosystem protection, economic development, social equity (Sperling and Berke, 2017), and provides directions to mitigate climate change and adapt to climate changes (Eftelioglu et al., 2016). The agricultural and food production sectors are at the center of the nexus concept because both sectors require significant amounts of water and energy for irrigation and food production: $70 \%$ of the global water withdrawals and $30 \%$ of the world's total energy consumption are allocated to this sector (FAO, 2017). Since the research on 
the nexus has started, several modelling tools have been developed. Nevertheless, most of the modelling approaches have only looked at interactions between two out of the three sectors, which is not optimal to improve resources efficiency (Kaddoura and El Khatib, 2017). Moreover, very few models are at the stage of implementing the WFE nexus approach (Dai et al., 2018; Shannak et al., 2018; Endo et al., 2019) and support the political decisions (Bazilian et al., 2011). Moreover, as highlight by Lawford (2019), there is a general data gap, both in the spatial and temporal dimensions, concerning the observation of key parameters for the WFE nexus analysis. Some examples of integrated WFE nexus tools development are provided in this section.

To minimize the economic and societal costs resulting from agricultural water shortages in Northeastern Colorado, Burrow et al. (2019) developed an optimization model including costs, penalties, unmet demands, topography, oversupply, and capacity to determine the capacity, configuration, and operation of water reservoirs. The authors showed that the implementation of the WFE nexus integrated model could support strategic decisions to avoid water shortages in key sectors. The authors also highlighted that the low water footprint of renewable energies, such as wind and solar power, could represent a sustainable path for electricity generation. Amjath-Babu et al. (2019) developed a hydro-economic model to investigate hydropower development in one Himalayan region. The model performed economic optimization of water management including irrigation and climate change. The authors highlighted that the flood and irrigation control performed through hydropower reservoirs was fundamental for meeting the Sustainable Development Goals (SDGs). Mahlknecht et al. (2020) studied the WFE security in the Latin America and Caribbean Region to study the interrelationship among those sectors. The authors developed a nexus-based index to evaluate those interlinkages among WFE resources. Through this WFE nexus framework, the authors highlighted a critical situation concerning energy conversion capabilities and water scarcity. Moreover, climate changes could negatively affect rainfall patterns, and accordingly reduce hydropower production and increase food imports. There are few studies conducted on the WFE nexus and agriculture in Sweden. Destouni et al. (2013) analyzed the hydro-climatic, agricultural and hydropower changes from the twentieth century in nine major basins in Sweden. The authors concluded that the evapotranspiration increased for irrigated and non-irrigated agriculture as well as for the hydropower sector. By extrapolating the results from regional to global scale, the authors highlighted the necessity for integrated climate and Earth system models to assess human water uses. This conclusion was drawn because the results obtained by the authors showed an increase of evapotranspiration larger than the corresponding planetary boundary as suggested by Rockström (2009). The study conducted by Jaramillo et al. (2013), which aligns with Wivstad et al. (2009) and Destouni et al. (2013) in terms of Sweden's agriculture development and the increased evapotranspiration, distinguished the effects of climate and land use. By analyzing the water balances, the authors concluded that the rapid increase of evapotranspiration was for about $30 \%$ due to climate changes while the rest $70 \%$ was due to shifts from semi natural grasslands to cultivated land.

All the reviewed approaches have shown that the awareness of the WFE nexus is increasing, the main challenge is still to increase the overlapping areas of integration among those sectors, and there is still lack of knowledge, expertise, information and tools, especially for operationally implementing the nexus (Liu et al., 2017).

\subsection{Irrigation management systems}

This section briefly summarize some of the research studies conducted on the topic of irrigation management systems. Wang et al. (2019) developed a web-based irrigation decision support system for canal irrigation management. The model is based upon two modules. The first module is for real-time irrigation forecast and scheduling. The second module is for planning the canals' water delivery volumes. In Italy, IRRINET is a decision support system for on-farm irrigation scheduling (Mannini et 
al., 2013), which gives the farmers day-by-day information on how much and when to irrigate crops. The system implements a real-time irrigation scheduling through climatic and meteorological data gathered daily. GREDRIP is a decision support system to minimize the pumping station's energy costs and adapt the irrigation network management to the crop distribution and water requirements (Lima et al., 2018). Mahmoud and Gan (2019) developed a model to enhance the irrigation water management in central Saudi Arabia by assessing the spatio-temporal variation of actual evapotranspiration through remote sensing techniques and meteorological data. Their study found out that the actual annual evapotranspiration estimated by the soil water balance model was around $9-11 \%$ higher than the modelled actual evapotranspiration in the studied area. Zhang et al. (2012) developed the ZhaoKou irrigation management system, consisting of a precipitation forecasting module, a crop water demand forecasting module, and a crop coefficient index. The established system improved water efficiency, providing a theoretical basis for water resources scheduling and channels' rational control. Galindo et al. (2017) presented a methodology for optimal water and energy management in the irrigation system using a two-layer management scheme. The upper layer is an optimal control strategy to plan how to serve the required water within a five-day prediction horizon to minimize pumping electricity costs. The lower layer is a scheduling algorithm that decides how to schedule the different pumps to supply the desired flow, minimize cost, and maximize efficiency. In Romania, a field-scale irrigation planning and management system was set up and tested (FutureWater, 2020). Irrigation guidelines are provided by integrating soil moisture content ground data with hydrological model calculations. In Greece, agriculture and especially irrigation plays a key role in terms of water management, and the IRMA_SYSTEM (2021) calculates site specific crop water requirements and irrigation scheduling at high spatial resolution (Malamos et al., 2015). The decision support system integrates historical and forecast agrometeorological data, crop data, and soil data to provide timely guidelines for irrigation. Other examples of decision support systems are FERTIRRIGERE (Battilani, 2004), a model-based decision support system used in Italy that proved to reduce the nitrogen application on horticultural products by $46 \%$ compared to conventional practices, with no notable effects on yield and quality. A comprehensive review of irrigation and fertilization decision support systems is provided in Gallardo et al. (2020).

Most of the current available irrigation management systems lack the WFE perspective, where information concerning irrigation water requirements, crop response to irrigation, and energy consumption are integrated. Thus, this study lays the foundations to develop an operational WFE nexus irrigation management system for Sweden, by including all the three areas of the nexus.

\section{Data and methods}

\subsection{Data}

This section describes the model updates with reference to previous works, and the development of the visualization platform. The gridded meteorological data used to generate the results are mainly taken from the mesoscale models Strång (2020) and Mesan (SMHI, 2020b) developed by SMHI. We have used as case study 2018, due to the serious drought that has affected the entire country, and 2019, as a normal year. The crop model used in this study refers to the model developed by Williams et al. (1989). A more detailed description of the WFE nexus model can be found in Zhang et al. (2018) and Campana et al. (2018). The crop mask has been built upon the data provided by the Swedish Board of Agriculture (2020). The groundwater depth dataset refer to the product developed by Fan et al. (2013). The soil field capacity and wilting point are from the Global Soil Data Task Group (2000). The irrigation areas refers to FAO (2016). The leaf area index used for improving the LAI sub model is from Copernicus Global Land Service (2020). The 2018 data concerning the flux tower have been retrieved from the Integrated Carbon Observation System Sweden (ICOS, 2019). Only one flux tower located at the agricultural 
research station of Lanna $\left(58^{\circ} 20^{\prime} \mathrm{N}, 13^{\circ} 06^{\prime} \mathrm{E}, 75 \mathrm{~m}\right.$ asl $)$ has been used for validation since it is the only available flux tower installed on an agricultural field in Sweden. A detailed description of the station and related measured variables can be found in ICOS (2021). Agricultural statistics were provided through personal communication with the station principal investigator (Weslien, 2020).

\subsection{Model updates}

This section describes the model updates with reference to previous works. As compared to the model presented in Campana et al. (2018), where the daily reference evapotranspiration $E T_{o}$ ( $\mathrm{mm} /$ day) was calculated using the Hargreaves and Samani equation (Hargreaves and Samani, 1982), in this study $E T_{o}$ has been calculated using the FAO-56 Penman-Monteith equation (Allen et al., 1998):

$$
E T_{o}=\frac{0.408 \Delta\left(R_{n}-G\right)+\gamma \frac{900}{T+273} u_{2}\left(e_{S}-e_{a}\right)}{\Delta+\gamma\left(1+0.34 u_{2}\right)}
$$

Where, $\Delta$ is the saturation slope of vapor pressure curve at $T_{a}\left(\mathrm{kPa} /{ }^{\circ} \mathrm{C}\right), R_{n}$ is the net radiation $\left(\mathrm{MJ} / \mathrm{m}^{2}\right.$ hour), $G$ is the soil heat flux density (MJ/m $/ \mathrm{m}^{2}$ hour), $\gamma$ is the psychrometric constant $\left(\mathrm{kPa} /{ }^{\circ} \mathrm{C}\right), T$ is the daily mean air temperature $\left({ }^{\circ} \mathrm{C}\right), e_{s}$ is saturation vapour pressure $(\mathrm{kPa}), e_{a}$ is the average daily actual vapour pressure $(\mathrm{kPa})$ and $u_{2}$ is the daily average wind speed $(\mathrm{m} / \mathrm{s})$. Zotarelli et al. (2010) have presented a detailed guideline for the step-by-step calculation of $E T_{o}$. In this study, the $E T_{o}$ and actual $E T\left(E T_{a}\right)$ estimates generated using the model and meteorological datasets described above have been validated using the flux tower installed at the agricultural research station of Lanna (ICOS, 2019). We validated the $E T_{a}$ estimates from the model using the latent heat flux data, and the soil water content model using the soil water content measurements collected at the site. The flux tower $E T_{a}$ is calculated with the following equation from $\mathrm{Gu}$ et al. (2017):

$$
E T_{a}=\frac{L E s}{\lambda \rho_{a}}
$$

Where, $L E$ is the latent heat flux $\left(\mathrm{W} / \mathrm{m}^{2}\right), s$ is the time (s), $\lambda$ is the latent heat of vaporization, and $\rho_{a}$ is the air density $\left(\mathrm{kg} / \mathrm{m}^{3}\right) . \lambda$ is calculated as follows (Moorhead et al., 2019):

$$
\lambda=\left(2.501-0.0236 T_{s}\right) 10^{6}
$$

Where, $T_{s}$ is the surface temperature $\left({ }^{\circ} \mathrm{C}\right)$. The surface temperature has been assumed equal to the air temperature as in Jungqvist et al. (2014). In SWEDIMS, the $E T_{a}$ is calculated using a water balance approach (Allen et al., 1998). To calculate the water balance, we considered that in 2018 oat was grown at the agricultural research station of Lanna (Weslien, 2020). The model has been thus set up for oat water balance and crop yield simulations. The ET in cultural conditions, a key component in the water balance, has been calculated with an iterative approach that minimizes the root mean square error between the $E T_{c}$ curve based on the FAO guidelines for oat development stages and corresponding cultural factors (Allen et al., 1998) and the $E T_{c}$ curve described by the following equation (DeJonge et al., 2012):

$$
E T_{c}=\left(a+b\left(1-e^{-c L A I}\right)\right)
$$

Equation 4 depends on the Leaf Area index $(L A I)\left(\mathrm{m}^{2} / \mathrm{m}^{2}\right)$ that is computed in the model through iterations (Zhang et al., 2018). A summary of the key model parameters for oats is given in Table 1. 
Table 1: Parameters for oats.

\begin{tabular}{lcc}
\hline Parameter & Value & Reference \\
\hline Harvest index & 0.42 & (Williams et al., 1989) \\
Biomass energy ratio $\left((\mathrm{kg} / \mathrm{ha}) /\left(\mathrm{MJ} / \mathrm{m}^{2}\right)\right)$ & 35 & (Williams et al., 1989) \\
Base temperature $\left({ }^{\circ} \mathrm{C}\right)$ & 0 & (Williams et al., 1989) \\
Optimal temperature $\left({ }^{\circ} \mathrm{C}\right)$ & 15 & (Williams et al., 1989) \\
Maximum LAI $\left(\mathrm{m}^{2} / \mathrm{m}^{2}\right)$ & 4 & (Myrbeck, 1998) \\
Water stress-yield factor & 0.21 & (Williams et al., 1989) \\
Potential heat units $\left({ }^{\circ} \mathrm{C}\right)$ & 1450 & (Balkovič et al., 2013) \\
LAI declining factor & 1 & (Williams et al., 1989) \\
Fraction of growing season when leaf area declines & 0.8 & (Williams et al., 1989) \\
First point on optimal leaf area development curve $(\%)$ & 15.01 & (Williams et al., 1989) \\
Second point on optimal leaf area development curve $(\%)$ & 50.95 & (Williams et al., 1989) \\
\hline
\end{tabular}

To improve the model accuracy, we have assimilated remote sensing data for $L A I$ into the crop model. From the $L A I$ data, significant information can also be deducted, such as the approximate crop planting date and the parameters of the leaf area development curve. Three scenarios have been considered. In the first scenario (S1-LAI), the $L A I$ is calculated as in Zhang et al. (2018) by using the default values as in Williams et al. (1989). In the second scenario (S2-LAI), the $L A I$ values for the closest coordinates at Lanna research station are retrieved from the Copernicus Global Land Service (CGLS, 2020) and directly fed into the model. In the last scenario (S3-LAI), the data assimilation is performed by minimizing the root mean square error (RMSE) between data generated by the developed model and the data from CGLS with a similar approach as carried out by Novelli et al. (2019) and Wagner et al. (2020). The optimization is performed through a genetic algorithm (GA) by using as decisional variables the key parameters that define the $L A I$ curve development: planting date, the growing season, the points that define optimal $L A I$ development curve, the $L A I$ decline factor and the fraction of the growing season at which the $L A I$ starts to decline. The implementation of more advanced data assimilation algorithms (Jin et al., 2018), such as Kalman Filter (KF) or Ensemble Kalman Filter (EnKF), is not included in this work because beyond its scope. Since this study has mainly focused on the comparison between irrigation guidelines, as described in more details in Section 3.3, the data assimilation is not applied in the calculation of the irrigation productivity while performing large-scale simulations.

\subsection{Irrigation management scenarios}

Although there is motivation to improve farm irrigation management to increase production, profit, and water use efficiency, it has to be pointed out that currently in Sweden only general irrigation guidelines are provided, for instance by Bergström and Barkefors (2004) combined with local experiences or tools developed for other agro ecologies outside of Sweden. There is thus a need of such tools and services to be designed for Swedish crop and climatic conditions (Barron, 2020). We used as a case study two counties in the south of Sweden, Blekinge and Skåne, which belong to statistical region (SE22) with the highest water consumption for irrigation as shown in Figure 2. 


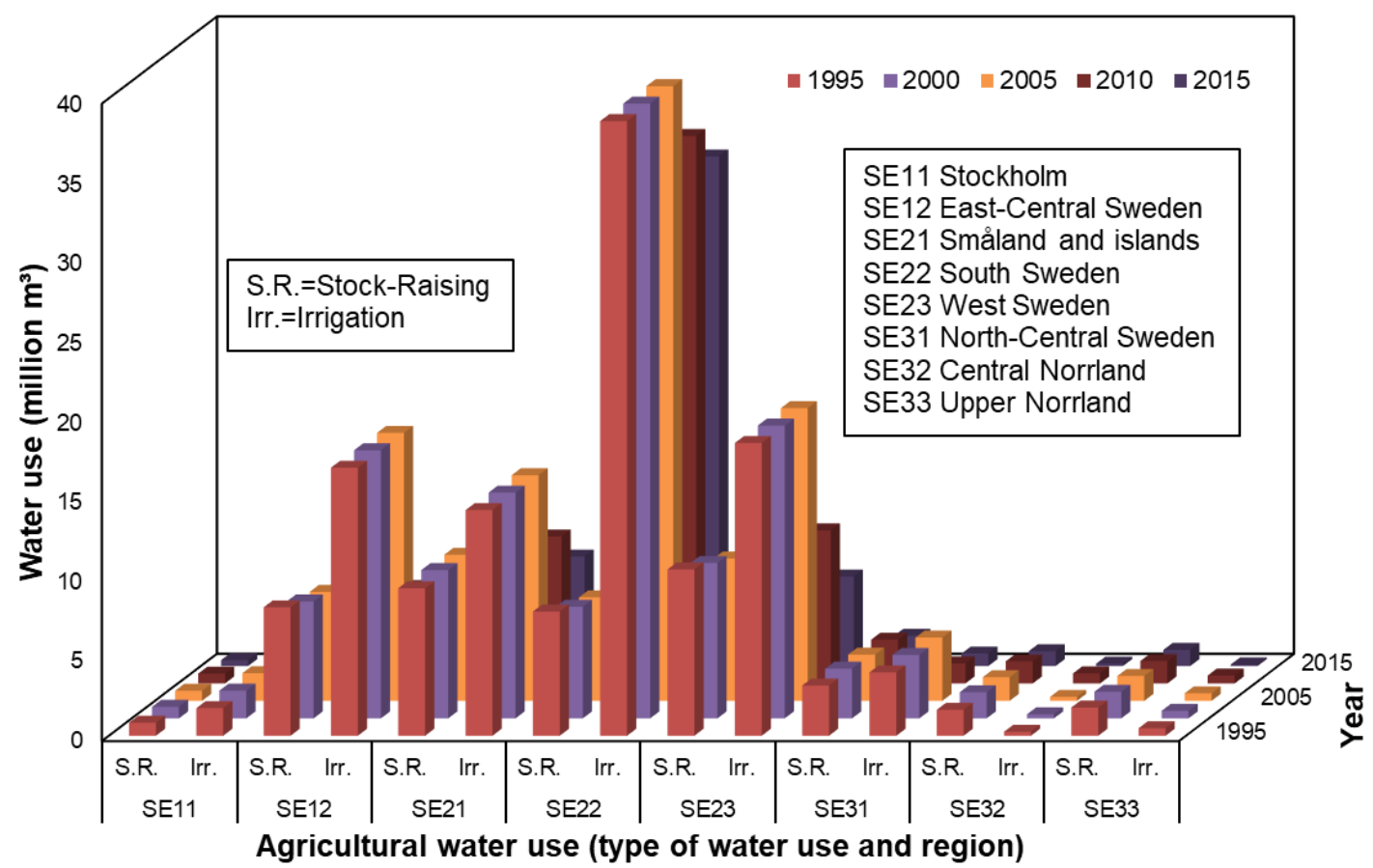

Figure 1: Agricultural water use, by type of water use and region in the period 1995-2015 (Statistic

Sweden, 2021).

Blekinge and in particular Skåne have the highest percentages of irrigated areas among cropland (FAO, 2016). We used potato as a reference crop, as in Campana et al. (2018), since it is the most irrigated crop in Sweden (Brundell et al., 2008). The total area cultivated with potatoes in Blekinge and Skåne in 2018 was 2,050 and 10,820 ha, respectively (Statistic Sweden, 2018). We thus have calculated the irrigation demand by using SWEDIMS and assuming that all the cultivated area is irrigated and the cultivated area is distributed among the grid cells equipped for irrigation (FAO, 2016). This approach is similar to Hughes et al. (2013), which also incorporated stochasticity in terms of irrigation requirements distributed in time, in Dutta et al. (2017), and in HYPE, the reference hydrological model for Sweden (SMHI, 2020c). Johnson et al. (2016) analysed the differences between irrigation following standard practices and irrigation based on decision support models that incorporate information on $E T$, such as the NASA SIMS model (Melton et al., 2012; Pereira et al., 2020). Based on two years of field data collected for head lettuce and broccoli using a randomized block design, the authors found that standard practices lead to an increase in water consumption between 26 and $40 \%$ for lettuce and between 39 and $51 \%$ for broccoli, as compared to ET-based irrigation management strategies based on data from SIMS. Crop yields and quality were very similar among the treatments, and no statistically significant differences in crop yield or quality differences were observed. Inspired by the results achieved by Johnson et al. (2016), we have developed three scenarios to analyse the impact of an irrigation management service as compared to conventional irrigation guidelines on the irrigation water productivity and water savings. Three scenarios have been defined for the irrigation requirements: in the first scenario (S1-irrigation ET), the irrigation demand follows the guidelines generated by the model developed in this study. According to Bergström and Barkefors (2004), 70\% of the potato area is irrigated in average with $100 \mathrm{~mm} / \mathrm{season}$ up to $200 \mathrm{~mm} / \mathrm{season}$ with 3 to 4 irrigation events. Slightly different values were presented in the report from the Swedish Board of Agriculture (2007) where the potatoes seasonal water requirement was between 300 and $350 \mathrm{~mm}$ assuming a rainfall of 170 to 250 $\mathrm{mm}$ during the irrigation season. 


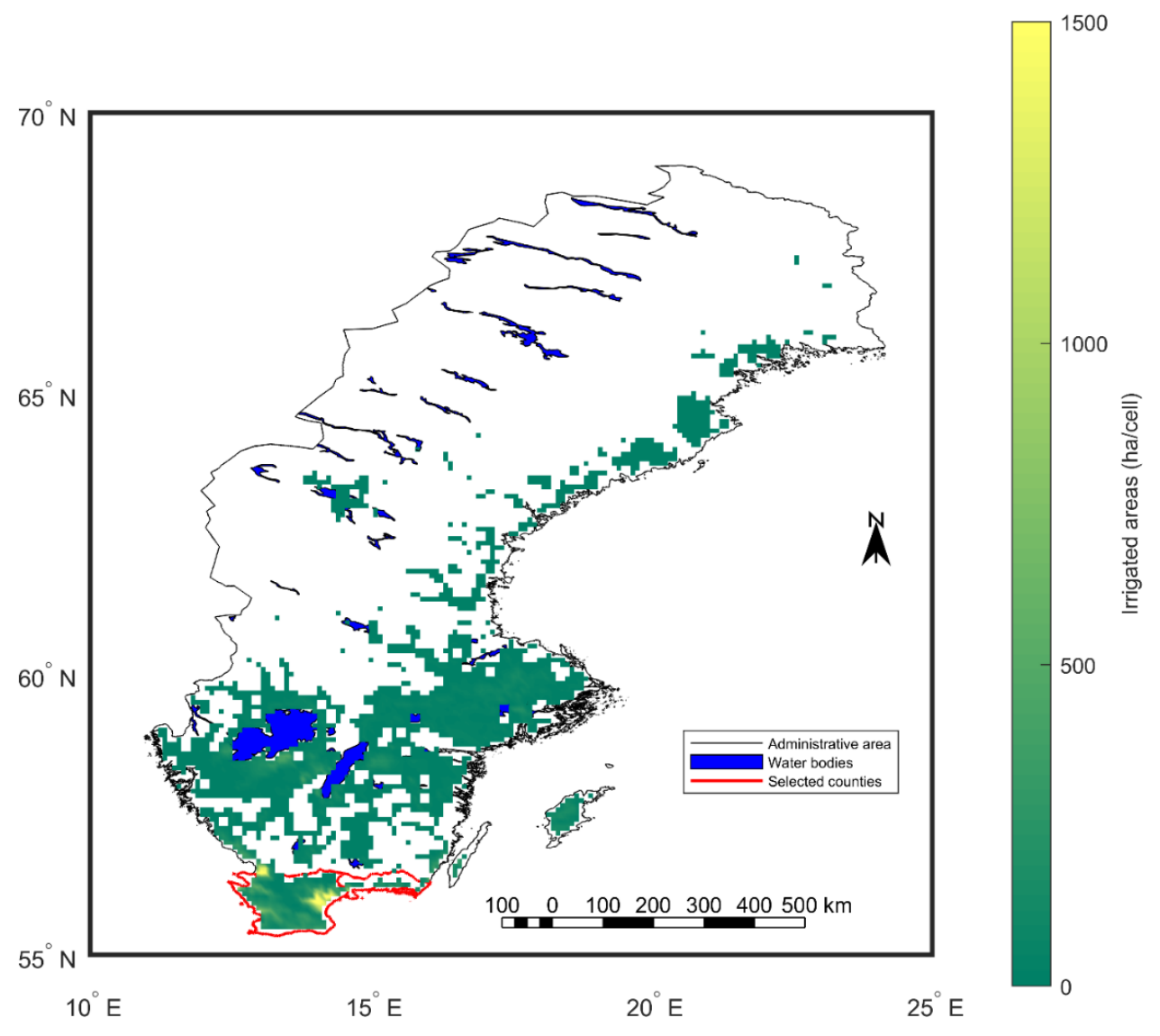

Figure 2: Irrigated areas in Sweden (FAO, 2016).

Based on those two static guidelines, we have thus considered two further scenarios: S2-irrigation static 100 consists of three irrigation events for a total of $100 \mathrm{~mm} / \mathrm{season}$ while S3-irrigation static 150 consisted in applying $150 \mathrm{~mm}$ in four events. A summary of the scenarios is provided in Table 3 . The results among irrigation guidelines are compared in terms of irrigation water productivity (IWP) $\left(\mathrm{kg} / \mathrm{m}^{3}\right)$, defined as the ratio between the different in crop yield with and without irrigation and the water applied through irrigation as in Bos (1985) and in Stepanovic et al. (2021). The irrigation follows an operational strategy similar to solar irrigation systems, which provide an optimal dynamic match between water demand and supply (Campana et al., 2015; Zhang et al., 2018). As compared to the previous study (Campana et al., 2018) where we assumed to keep the soil moisture constant, in this study irrigation is performed only when the water stress coefficient $\left(K_{s}\right)$ as defined in Allen et al. (1998) goes below the unity. Different from previous studies (Campana et al., 2015; Zhang et al., 2018), no optimization is performed or investigated in this study. 
Table 3: Irrigation scenarios definition.

\begin{tabular}{cccc}
\hline Sensitive parameter & S1-irrigation ET & S2-irrigation static 100 & S3-irrigation static150 \\
\hline $\begin{array}{c}\text { Irrigation method } \\
\text { Irrigation efficiency } \\
\text { Description }\end{array}$ & $\begin{array}{c}\text { Sprinkler } \\
90 \%\end{array}$ & $\begin{array}{c}\text { Sprinkler } \\
90 \%\end{array}$ & $\begin{array}{c}\text { Sprinkler } \\
90 \%\end{array}$ \\
& $\begin{array}{c}\text { Water is provided according to } \\
\text { the scheduling proposed by the } \\
\text { model developed in this study } \\
\text { based on the } K_{s} \text { value }\end{array}$ & 3 irrigation events for a total of & 4 irrigation events for a total of \\
& - & $100 \mathrm{~mm} / \mathrm{season}$ & $150 \mathrm{~mm} / \mathrm{season}$ \\
Reference & & Bergström and Barkefors & Swedish Board of Agriculture \\
& & $\begin{array}{c}\text { (2004), irrigation of } 100-200 \\
\text { mm/season with } 3 \text { to } 4\end{array}$ & $\begin{array}{c}\text { 300-350 mm assuming a } \\
\text { rainfall of } 170 \text { to } 250 \\
\text { irrigation events }\end{array}$ \\
& & & mm/season \\
\hline
\end{tabular}

\subsection{Water-energy nexus}

The energy consumption of irrigation systems depends mainly on irrigation water volumes, hydraulic head, and pumping system. Several other micro aspects such as irrigation strategy, irrigation system, and fuel affect those factors. Equation 5 summarizes all these parameters to allow a comprehensive calculation of the energy requirements for irrigation $E_{\text {irr }}(\mathrm{kWh})$. An overview of the parameters affecting the energy consumption of irrigation system is given in Figure 3.

$E_{i r r}=c f \frac{\frac{E T_{c}-P_{e}}{\eta_{i r r}(1-L R)} A\left(\mathrm{SH}+\mathrm{d}+\mathrm{H}_{i r r}+\sum \lambda+\sum \zeta\right)}{\eta_{m} \eta_{p}}$

Where, $c f$ is a conversion factor equal to 0.0027 that takes into consideration the density of water (1000 $\left.\mathrm{kg} / \mathrm{m}^{3}\right)$, gravity acceleration $\left(9.8 \mathrm{~m} / \mathrm{s}^{2}\right)$, and the conversion between Joule and $\mathrm{kWh}\left(1 /\left(3.6 \cdot 10^{6}\right)\right), E T_{c}$ is the evapotranspiration in cultural conditions $(\mathrm{m}), P_{e}$ is the effective precipitation $(\mathrm{m}), A$ is the irrigated area $\left(\mathrm{m}^{2}\right), \eta_{i r}$ is the efficiency of the irrigation system (\%), LR is the leaching requirement (\%), $S H$ is the static head (m), $d$ is the drawdown (m), $H_{\text {irr }}$ is the required head to operate the irrigation system (m), $\lambda$ and $\xi$ are continuous and concentrated head losses $(\mathrm{m}), \eta_{m}$ is the motor efficiency, and $\eta_{p}$ is the pump efficiency (\%). The drawdown depend on the specific borehole performance and it is site-specific as it varies with the geologic properties of the location (e.g., permeability, storage capacity). From a WFE nexus perspective, Equation 5 encloses the relationships among water, energy, food, and soil for irrigation systems. The soil aspect of Equation 5 is related with the irrigation shifts and thus irrigation scheduling that typically depends on the field capacity and wilting point of the soil in irrigation water management. The irrigation shift $I_{s}$ (day) is calculated as the ratio between the irrigation height and the irrigation water requirements ( $\mathrm{mm} /$ day):

$I_{s}=\frac{\frac{E T_{c}-P_{e}}{\eta_{i r r}(1-L R)}}{f\left(\theta_{f c}-\theta_{w p}\right) d}$

Where $f$ is the fraction of the total available water that can be used by the plant stress, $\theta_{f c}$ if the soil field capacity $(\mathrm{mm} / \mathrm{m}), \theta_{w p}$ is the soil wilting point $(\mathrm{mm} / \mathrm{m})$, and $d$ is the crop root depth $(\mathrm{m})$. The main efficiencies involved in the calculation of the energy requirements for irrigation and their respective variations are summarized in Table 2. By taking into consideration all the aspects described in this section, we have presented in Section 4 a case study on energy consumption for irrigation for two Swedish counties, Blekinge and Skåne. Two scenarios (Scenarios 1 and 2) are defined, which represent the worst and best cases in terms of energy consumption in irrigation. The parameters of those two investigated scenarios are summarized in Table 4. 


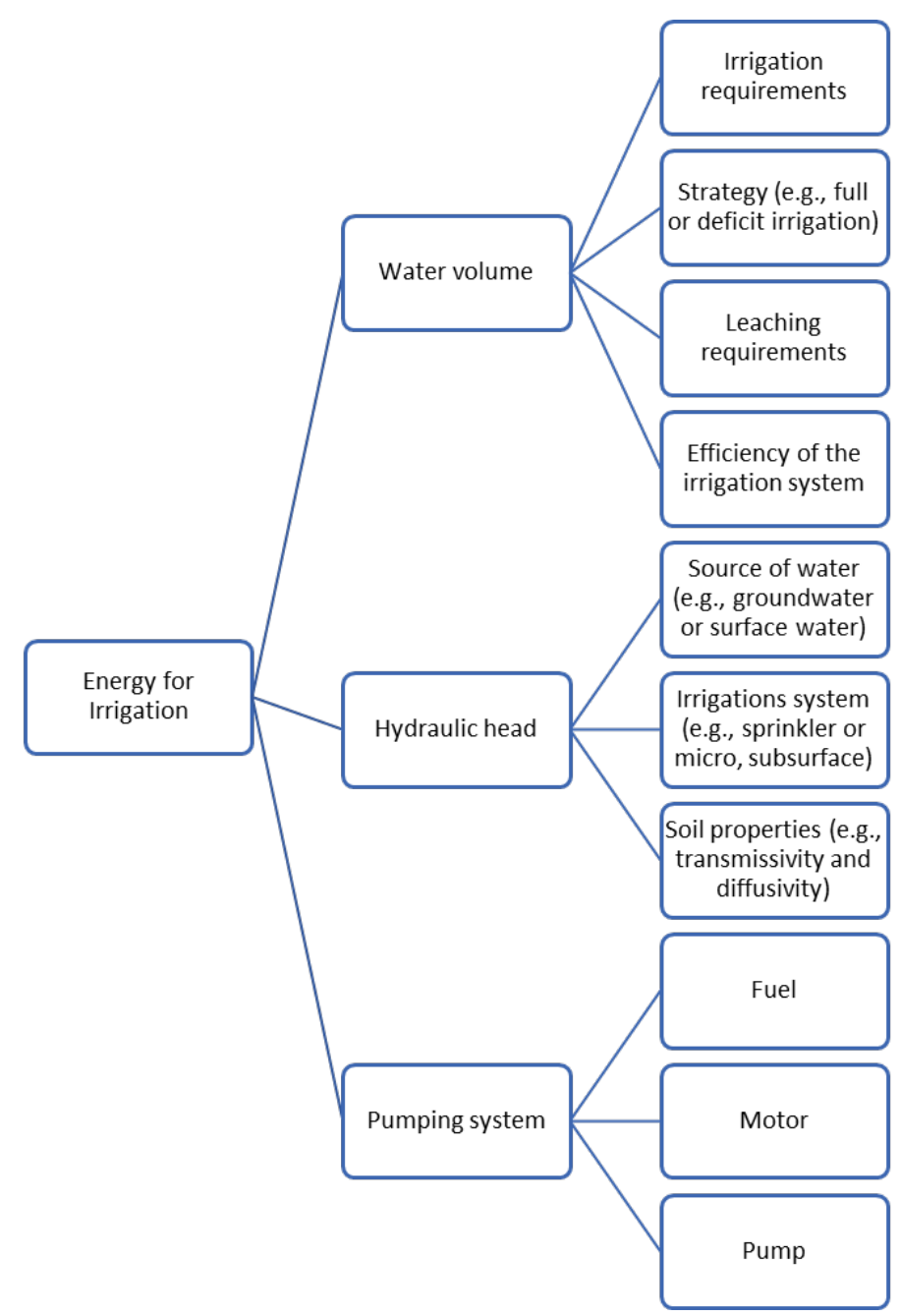

Figure 3: Parameters affecting the energy consumption in irrigation systems.

Table 2: Summary of main efficiencies and working pressures involved in irrigation systems operation.

\begin{tabular}{|c|c|c|}
\hline Parameter & Value & Reference \\
\hline Irrigation system efficiency (\%) & $\begin{array}{l}\text { Surface } 45-80 \% \text { Sprinkler } 65-90 \% \text { Micro } 80- \\
95 \% \text {, Subsurface } 95-98 \%\end{array}$ & $\begin{array}{l}\text { (Irmak et al., 2011), (Ehmke, } \\
\text { 2014) }\end{array}$ \\
\hline Motor efficiency (\%) & $\begin{array}{l}40 \% \text { diesel powered } \\
90 \% \text { electric powered }\end{array}$ & (Daccache et al., 2014) \\
\hline Pump efficiency (\%) & $40-90$ & (Martin-Candilejo et al., 2020) \\
\hline Irrigation pressure & $\begin{array}{l}\text { Low Pressure } 2-35 \mathrm{psi}^{*} \\
\text { Moderate Pressure } 35-50 \mathrm{psi}^{*} \\
\text { Medium Pressure } 50-75 \mathrm{psi}^{*} \\
\text { High Pressure } 75+\mathrm{psi}^{*} \\
\text { Surface irrigation } 0 \text { bar } \\
\text { Drip irrigation } 1 \text { bar } \\
\text { Sprinkler irrigation } 3 \text { bar }\end{array}$ & $\begin{array}{l}\text { (USDA NRCS, 1997), } \\
\text { (Espinosa-Tasón et al., 2020), } \\
\text { (Daccache et al., 2014), } \\
\text { (Phocaides, 2000) }\end{array}$ \\
\hline
\end{tabular}


Table 4: Energy scenarios definition.

\begin{tabular}{ccc}
\hline Sensitive parameter & S1-energy & S2-energy \\
\hline Irrigation method & Sprinkler & Micro \\
Irrigation efficiency & $75 \%$ & $90 \%$ \\
Water source & Groundwater & Surface water \\
Power source & Diesel & Electric grid \\
Pump efficiency & $60 \%$ & $90 \%$ \\
\hline
\end{tabular}

Shortly, Scenario 1 (S1-energy) represents the worst case in terms of energy consumption. It refers to the adoption of a sprinkler irrigation fed by a diesel-powered pump that uses groundwater as water source. Scenario 2 (S2-energy) refers to an electricity powered micro irrigation system that pumps water from a nearby surface water source. S1 has higher energy consumption than S2 because of the higher hydraulic head (depth of the water sources and required pressure for the irrigation system), higher water consumption (lower efficiency of the irrigation system), and lower efficiency of the pumping system (power source and pump efficiency).

\subsection{Development of the visualization platform}

The current version of the developed model relies on Google Earth Pro ${ }^{\circledR}(2021)$ for the visualization (SWEDIMS, 2021). The model retrieves data from the SMHI models Strång (2020) and Mesan (SMHI, 2020b), which are further processed with the model presented in this study. The gridded data are uploaded to the web database (SWEDIMS, 2021). Once the gridded data are stored, a parallel code develops a KML file to visualize the spatial data for the entire country. The generated KML file also allows the retrieval of time-series image data as well as MS Excel files for more than 300 locations across the country. The KML file has been developed using the open-source package Google Earth Toolbox developed by Scott Lee Davis (2020).

\section{Results and discussions}

\subsection{Model validation}

The comparison of reference evapotranspiration and crop yield using Penman-Monteith $\mathrm{ET}_{\mathrm{o}}$ versus the Hargreaves and Samani equations for reference ET is depicted in Figure 4 (scatter plot of reference evapotranspiration on the left and difference in crop yield on the right). As it can be seen, the Hargreaves and Samani equation slightly underestimates $E T_{0}$ as compared to Penman-Monteith as also highlighted in the study conducted by Awal et al. (2020). Nevertheless, the absolute difference in crop yield estimation is $0.11 \mathrm{t} / \mathrm{ha}$, less than $2.5 \%$. This result can have practical consequences on the implementation of the reference evapotranspiration model, since Penman-Monteith requires significant more input data as compared to Hargreaves and Samani's model. The validation of the simulated actual evapotranspiration $\left(E T_{a}\right)$ is presented in Figure 5 using $E T_{a}$ derived from the flux tower. The scatter plot shows an $\mathrm{R}^{2}$ of 0.80 and RMSE of 1.38 between the derived and simulated daily $E T_{a}$ during the crop-growing season using Penman-Monteith for the calculation of $E T_{0}$. The $\mathrm{R}^{2}$ is 0.78 while the RMSE is 1.17 when the Hargreaves and Samani equation is implemented. This shows a good agreement between measured and modelled data with Zhang et al. (2016), which reported an $\mathrm{R}^{2}$ of 0.549 between flux-tower derived ET to MODIS ET product. The relationship between the soil water content based on the daily values calculated from SWEDIMS and the values measured at the Lanna FLUXNET station for different depths is presented in Figure 6. The calculated soil water content refers to the value within the crop root depth $(\max 1 \mathrm{~m})$, and is based on the water balance for the grid cell of $2.5 * 2.5 \mathrm{~km}$ (resolution of the gridded input data of Strång and Mesan) containing the agricultural station. Good agreement is observed between the measured and simulated values, especially with the soil water content at $0.3 \mathrm{~m}$ depth. It has to be pointed out that in the simulations of the soil water content, capillarity was 
not included. Moreover, it is worth to note two important aspects. First, the calculation of the soil water content has been performed by assuming that at the beginning of the simulations the soil water content was at field capacity. Second, the field capacity is extracted by a gridded product (Global Soil Data Task Group, 2000) that can not represent accurately the heterogeneity of soil properties at field level.
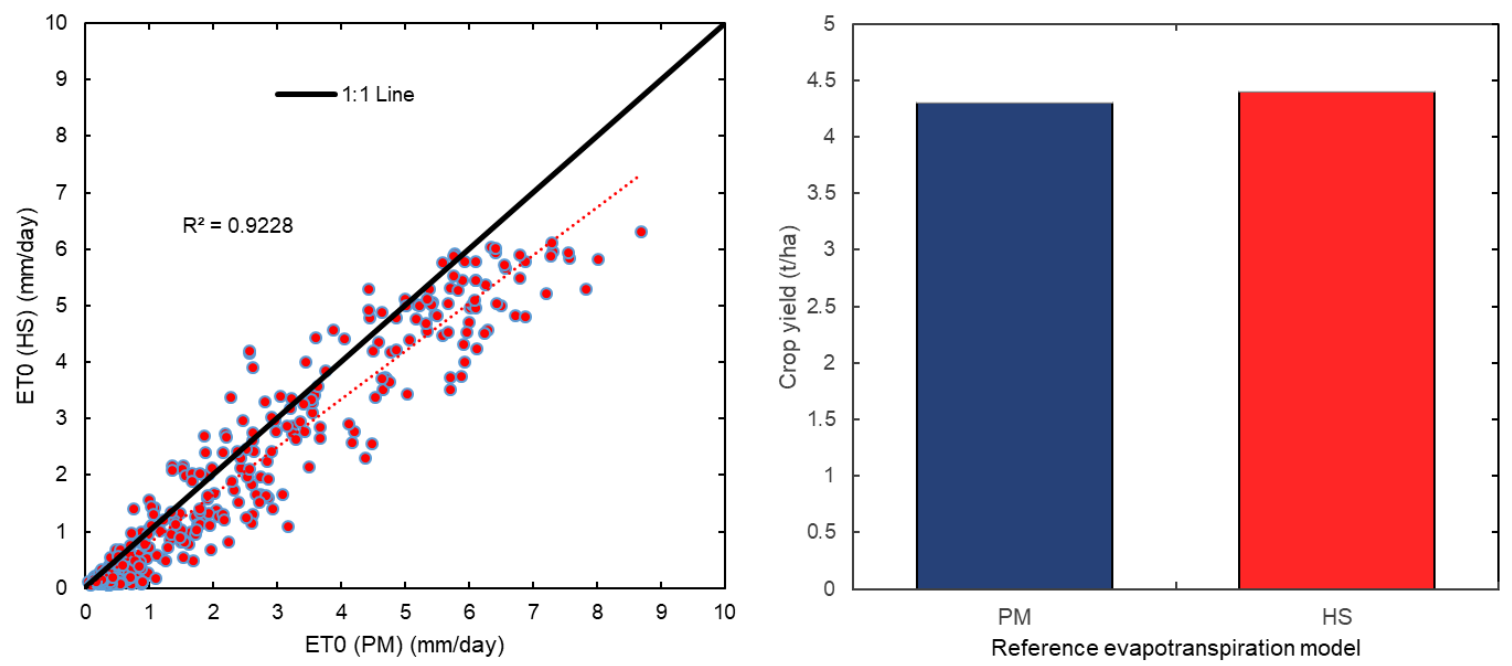

Figure 4: Comparison between reference evapotranspiration (left) and crop yield (right) by using the Penman-Monteith (PM) and the Hargreaves and Samani (HS) equations for the year 2018.
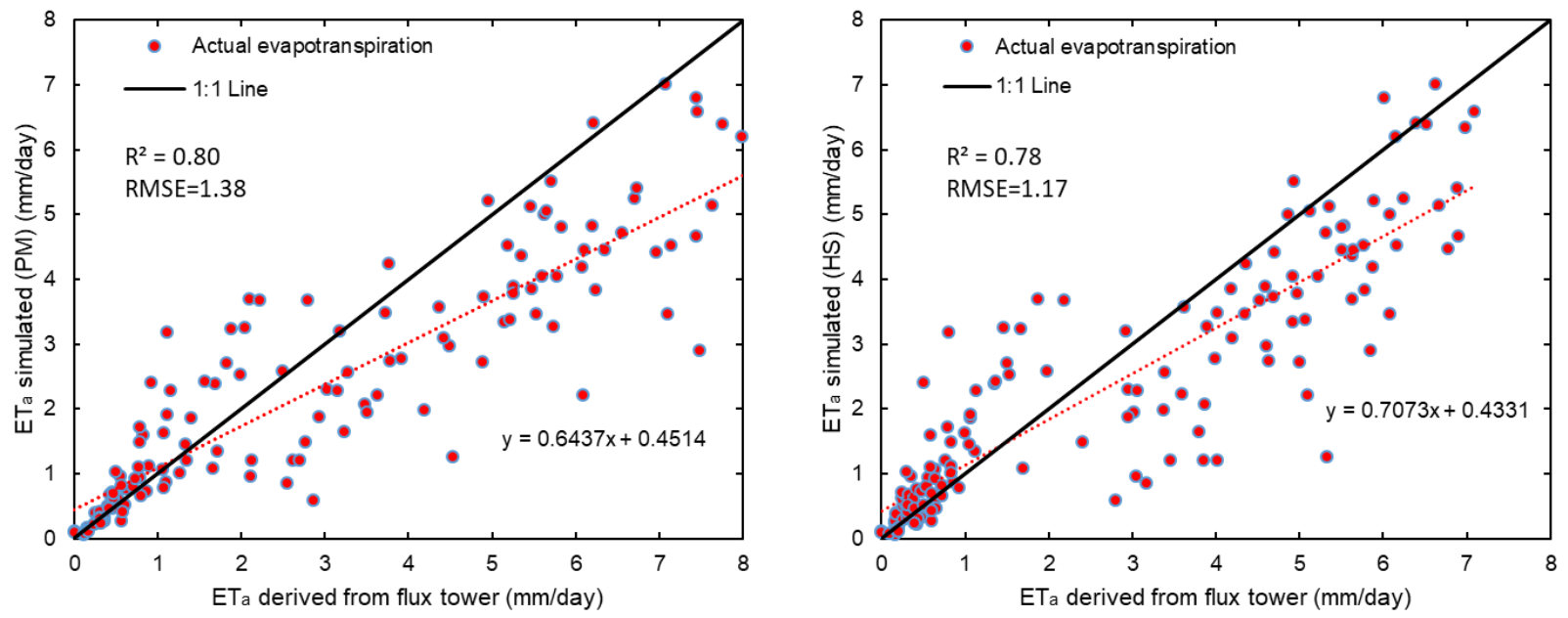

Figure 5: Relationship between measured and calculated actual evapotranspiration using the PenmanMonteith (PM) and the Hargreaves and Samani (HS) equations for the year 2018 during the cropgrowing season). 


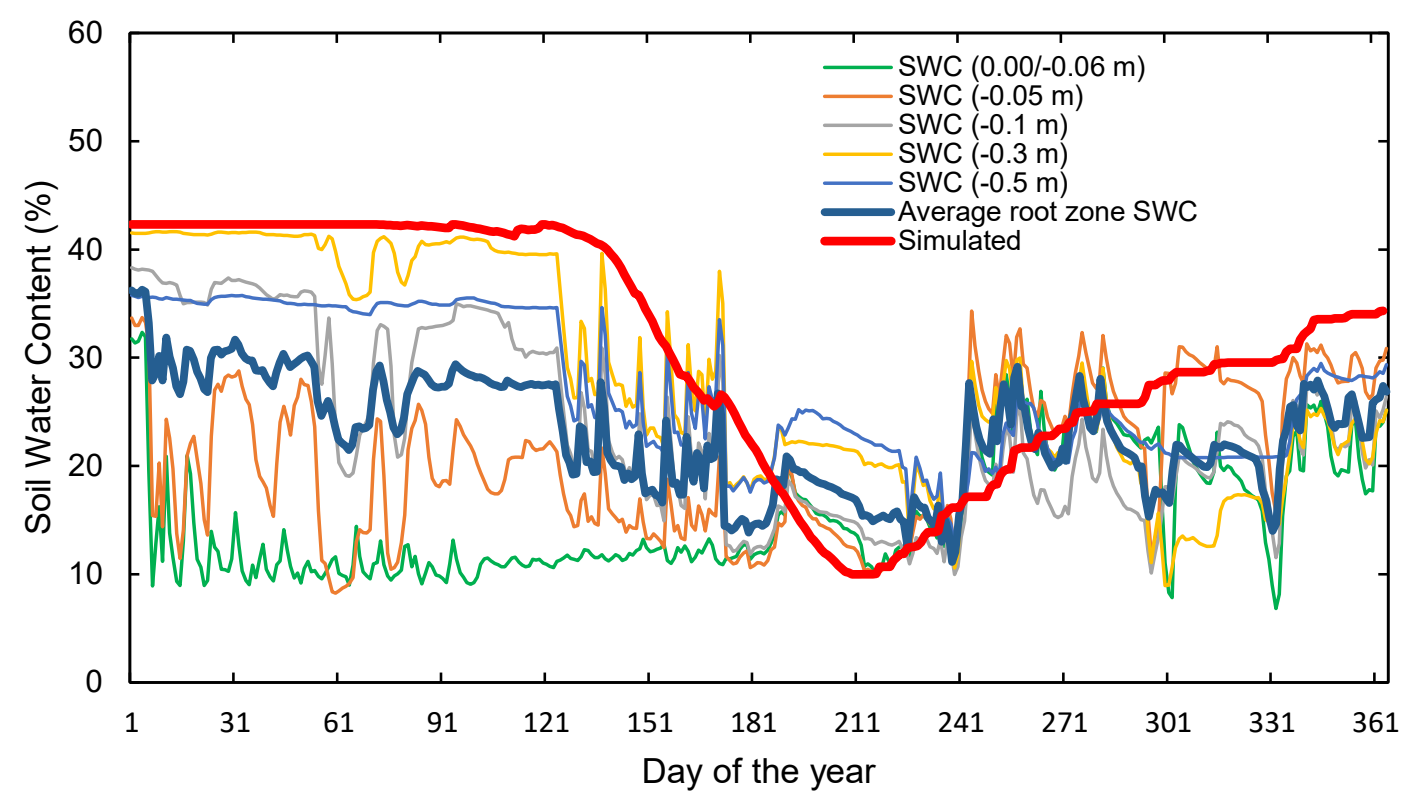

Figure 6: Measured soil water content at different depths at the Lanna FLUXNET station and calculated soil water content within the crop root depth for the year 2018.

The results of the crop yield validation at the agricultural research station of Lanna are depicted in Figure 7. The crop yields simulated with the model used in this study were compared with the crop yield retrieved from the station principal investigator (Weslien, 2020) and Statistics Sweden (2018). The harvest at the station was approximately 5 t/ha as reported by Weslien (2020). The oat yield from Statistics Sweden (2018) refers to the 2018 county-level oat yield in Västra Götaland County, where the Lanna research station belongs. The simulation results in Figure 7 show very good agreement especially with the county-level average yield, considering that the current version of the model runs at a resolution of $2.5 \mathrm{~km}$ and may not provide accurate crop yield estimations at the field level due to the heterogeneity of the required input parameters. In particular, the model is sensitive to parameters, such as planting date, $L A I$, and soil moisture. As can be seen in Figure 7, the yield generated from the model using $L A I$ data assimilation with optimization (S3-LAI) as carried out by Novelli et al. (2019) and Wagner et al. (2020) shows the most accurate results as compared to the actual measured yield. The percent error as compared to the measured crop yield and the county-level statistics is $2 \%$ and $10.6 \%$, respectively. Those results are in agreement with the results presented by Wagner et al. (2020), which demonstrated the superiority of the optimization method as compared to simple updating. The authors also demonstrated that the optimization approach could lead to similar or even improved results as compared to more advanced data assimilation algorithms such as the extended Kalman filter updating. The $L A I$ curve after optimization of the shape key parameters and the $L A I$ data from CGLS are depicted in Figure 8. The crop yield simulations using the default crop parameters as in Williams et al. (1989) show similar results by providing simple updates of $L A I$ values from CGLS (Figure 7). The $L A I$ data from CGLS comes with a five-day delay. In an operational system, this could lead to some inaccuracies for estimating the water use for irrigation and crop yield (i.e., the potential biomass accumulation). This aspect is not investigated in this study but will be assessed in future experimental studies. Balkovič et al. (2013) reported similar yields for oat in their comprehensive EPIC multi-crop simulation across 
Europe. Foltescu (2000) reported similar yields by running the WOFOST crop model using Mesan climatological parameters as input.
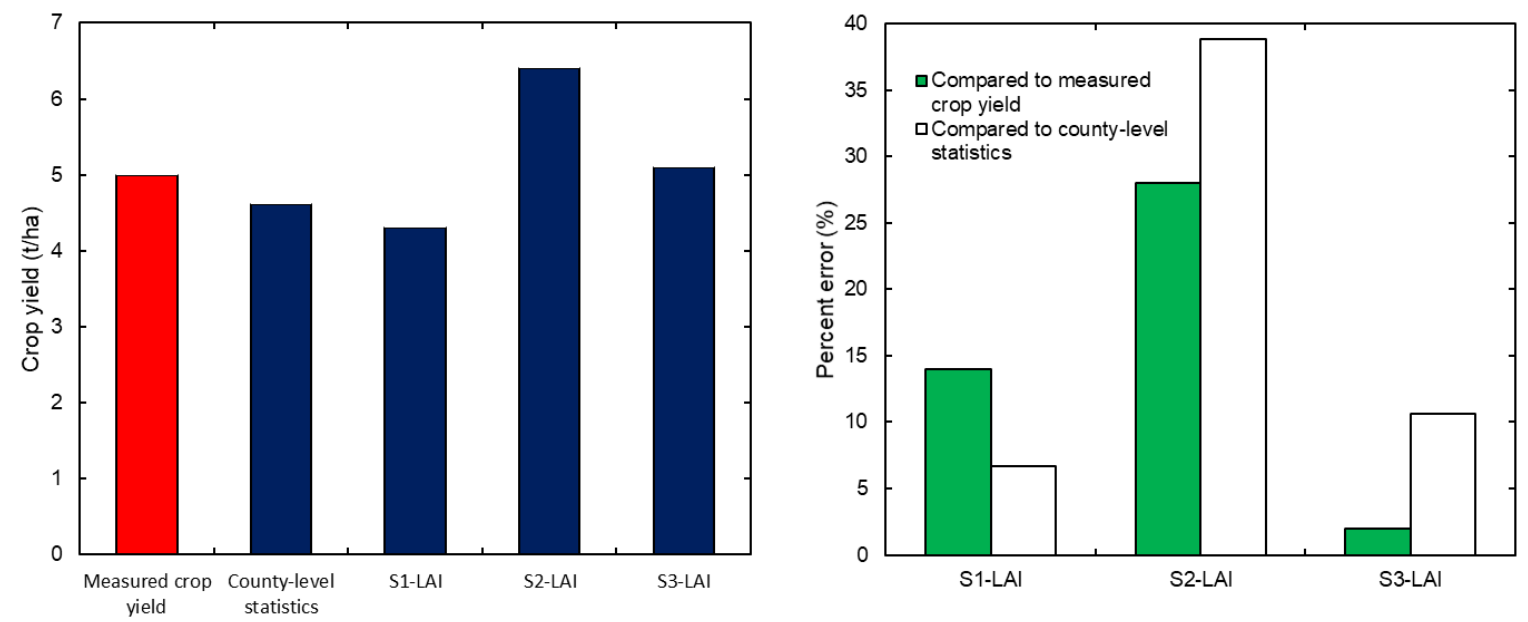

Figure 7: Crop yield validation for the year 2018.

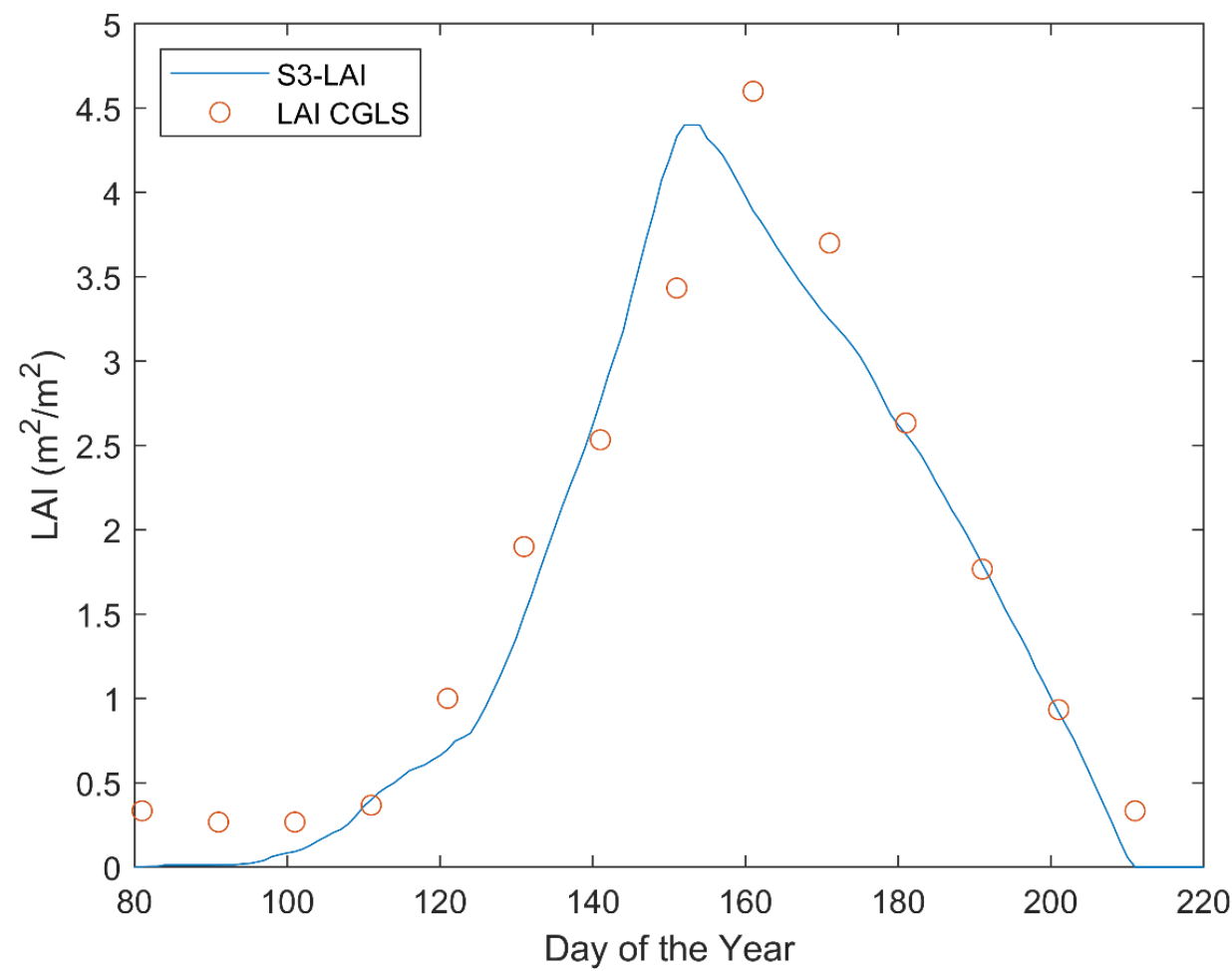

Figure 8: Time series of assimilated leaf area index and Copernicus Global Land Service (CGLS) leaf area index observations for the year 2018.

\subsection{Irrigation water productivity}

The results of the irrigation water productivity $(I W P)\left(\mathrm{kg} / \mathrm{m}^{3}\right)$ for the investigated irrigation scenarios are summarized in Figure 9 for 2018 and in Figure 10 for 2019. The irrigation guidelines provided by the model developed in this study shows the highest values of IWP in most of the considered grids both for 2018 and 2019. The scenarios S2-irrigation static 100 and S3-irrigation static 150 derived from Bergström and Barkefors (2004) and from the Swedish Board of Agriculture (2007) show lower IWP 
values in both 2018 and 2019. As compared to scenarios S2 and S3-irrigation, the guidelines provided by the developed spatially-explicit model shows higher water volumes for irrigation (i.e., negative water savings in Figure 11), but maintains higher IWP values in most of the grids as it can be seen in Figure 9. In 2018 , the proposed irrigation management system could lead to water savings mostly between -75 and $-50 \%$ as compared to S2-irrigation static 100 and between -65 and $-25 \%$ as compared to S3irrigation static 150 as depicted in Figure 11 (left). Nevertheless, by analyzing the crop yield reduction of scenarios S2-irrigation static 100 and S3-irrigation static 150 (see Figure 9 (right)) as compared to scenario S1-irrigation ET, it can be easily noted that crop yield reductions from conventional irrigation guidelines varies between 20 to $80 \%$. Most of the input data for irrigation management varies temporally and spatially, making spatially-explicit guidelines fundamental. Meanwhile, with intensifying climate changes and more frequent extreme weather events in recent years, such as the severe drought in 2018, it becomes more difficult to apply the "typical meteorological" year guidelines based on past experiences (Melton et al., 2012). By analyzing the results concerning water savings and crop yield reduction for 2019, a more "typical meteorological" year as compared to 2018, we can see that most of the water savings range between $-60 \%$ to $90 \%$ as compared to scenario S2-irrigation static 100 and between -40 to $95 \%$ as compared to scenario S3-irrigation static 100 . Even in 2019, by assuming static guidelines, the crop yield reduction as compared to S1-irrigation ET ranges between -5 to $70 \%$. By comparing S1-scenario with S3-scenario, those modelling results align with Johnson et al. (2016), which demonstrated the implementation of a large-scale irrigation management service (i.e., NASA SIMS) can lead to water savings of up to $50 \%$ relative to conventional irrigation practices. A further model run for scenario S1-irrigation ET was performed by using a threshold value for $K_{s}$ equals to 0.6 (i.e., irrigation is performed only when the water stress coefficient reaches a value of 0.6). The results are summarized in Table 5 only for one single grid point $\left(56.01^{\circ} \mathrm{N}, 14.43^{\circ} \mathrm{E}\right)$. As it can be seen, both scenarios suggest a similar applied irrigation height, nevertheless, the crop yield for scenario S1irrigation ET is significantly higher than for Scenario S3-irrigation due to a better irrigation scheduling (i.e., when to irrigate and how much irrigate). This further justifies, at parity of irrigation height, the superiority of spatially-explicitly $E T_{c}$-driven guidelines as compared to conventional non-spatially and temporally driven irrigation guidelines. $E T_{c}$-driven irrigation was also acknowledged by Ko and Piccinni (2009) as one the efficient irrigation schemes to achieved higher water use efficiency for growing corn in Texas. Similar, Hanson and Putnam (2000) pointed out that water consumption in irrigation for Alfalfa in California can be reduced through an improved irrigation scheduling by considering dynamic variation of $E T_{c}$ and soil moisture. The authors also investigated the effects of deficit irrigation and pointed out that further water savings in irrigation can be achieved by reducing or avoiding irrigation during those periods when the crop yield per water applied is minimal. Similar conclusions for maximizing Alfalfa water use efficiency in the Great Plains and Intermountain were achieved by Lindenmayer et al. (2011).

In 2018, crop reduction due to temperature stress was up to $35 \%$ as compared to the ideal case without temperature stress (Figure 13). The results refer to two cases: no irrigation and S1-irrigation ET. Since the WFE nexus also represents a framework for innovations and technologies for sustainable natural resources management, an important technology that could be integrated in the agricultural and irrigation sector to reduce the impacts of water and temperature stresses on crops is agrivoltaic (i.e., the combination of photovoltaic systems and crop production in the same area). Agrivoltaic systems, as well as photovoltaic water pumping systems for irrigation, can simultaneously address the interactions among water, energy, and food. Due to the shadings on the crops, Amaducci et al. (2018) demonstrated that agrivoltaic systems with an optimal density of PV modules can increase crop yields due to their capability of keeping higher level of soil moisture. Similarly, Barron-Gafford et al. (2019) showed that 
the combination of PV systems with farm activities could lead to reduced drought impact, and higher food yield.

Table 5: Comparison between scenario S1-irrigation ET and S3-irrigation static 150 for one single grid point. Scenario S1-irrigation ET is obtained by using a threshold of the water stress coefficient of 0.6 .

\begin{tabular}{ccc}
\hline Scenario & $\begin{array}{c}\text { Applied } \\
\text { irrigation } \\
(\mathbf{m m} / \text { season) }\end{array}$ & $\begin{array}{c}\text { Crop yield } \\
(\mathbf{t} / \mathbf{h a})\end{array}$ \\
\hline S1-irrigation ET & 152.7 & 13.3 \\
S3-irrigation static 150 & 150.0 & 9.4 \\
\hline
\end{tabular}



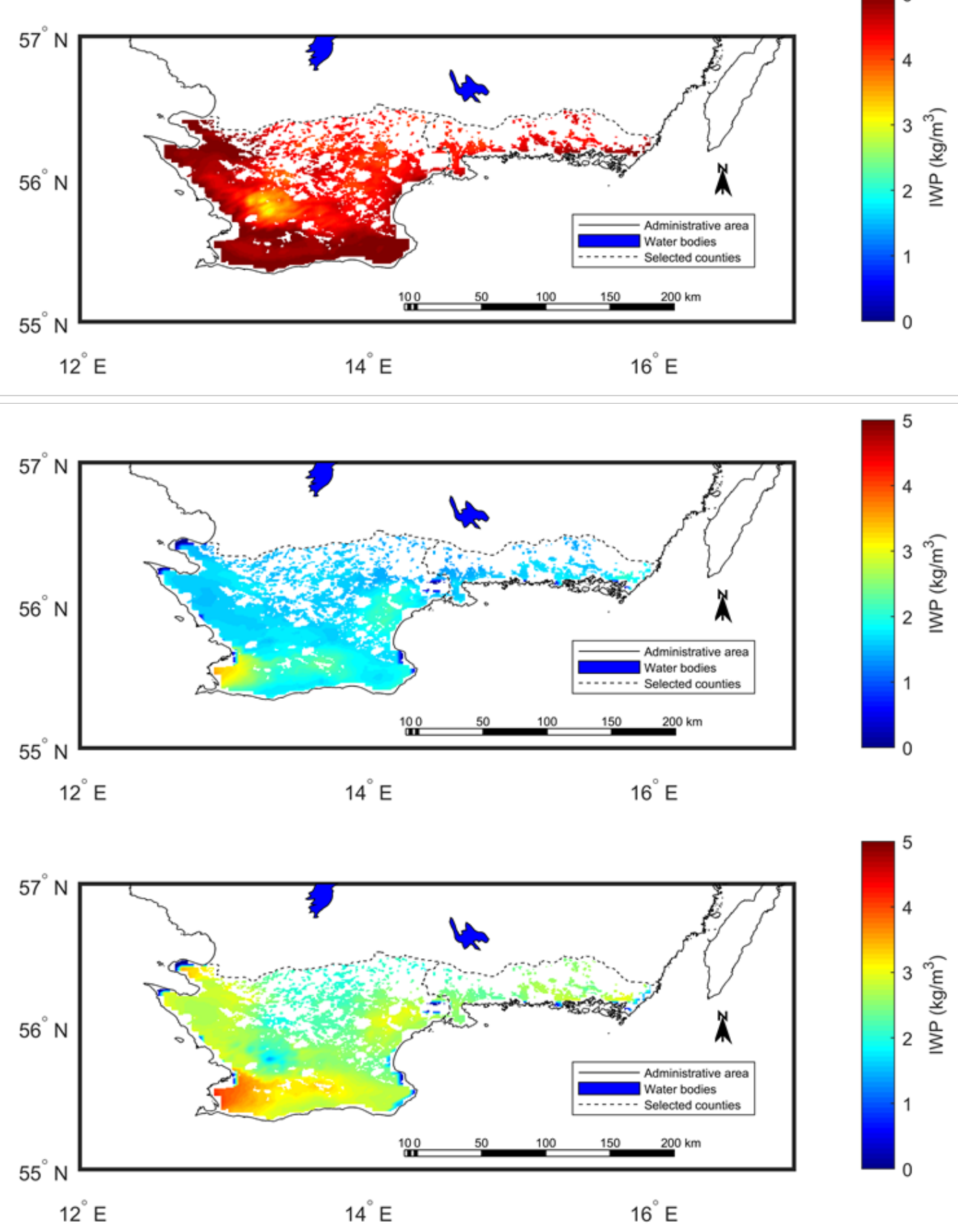

Figure 9: Irrigation water productivity (IWP) (according to the guidelines from SWEDIMS (S1irrigation ET) (top), S2-irrigation static 100 (center), and S3-irrigation static 150 (bottom)) in 2018. 

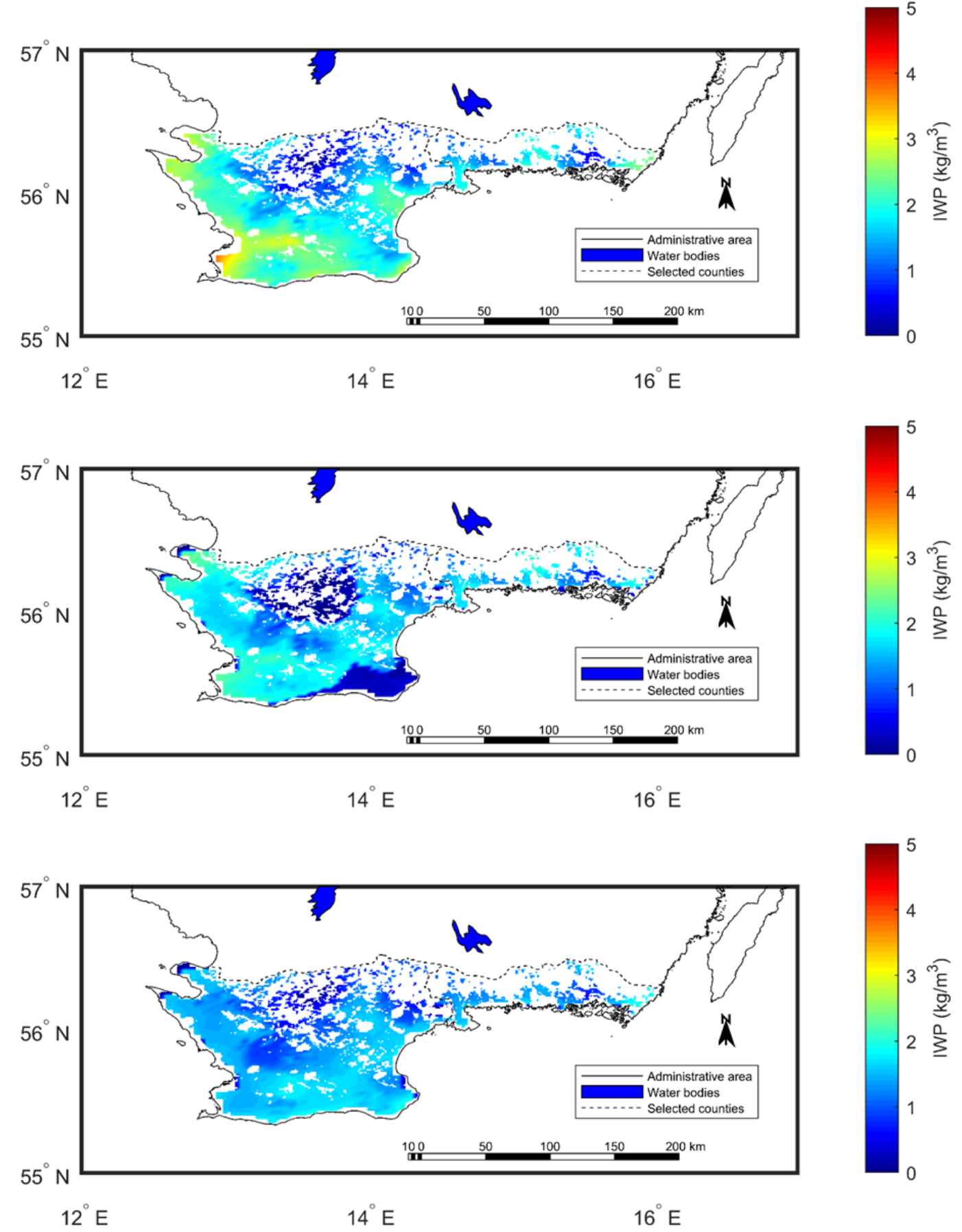

Figure 10: Irrigation water productivity (IWP) (according to the guidelines from SWEDIMS (S1irrigation ET) (top), S2-irrigation static 100 (center), and S3-irrigation static 150 (bottom)) in 2019. 

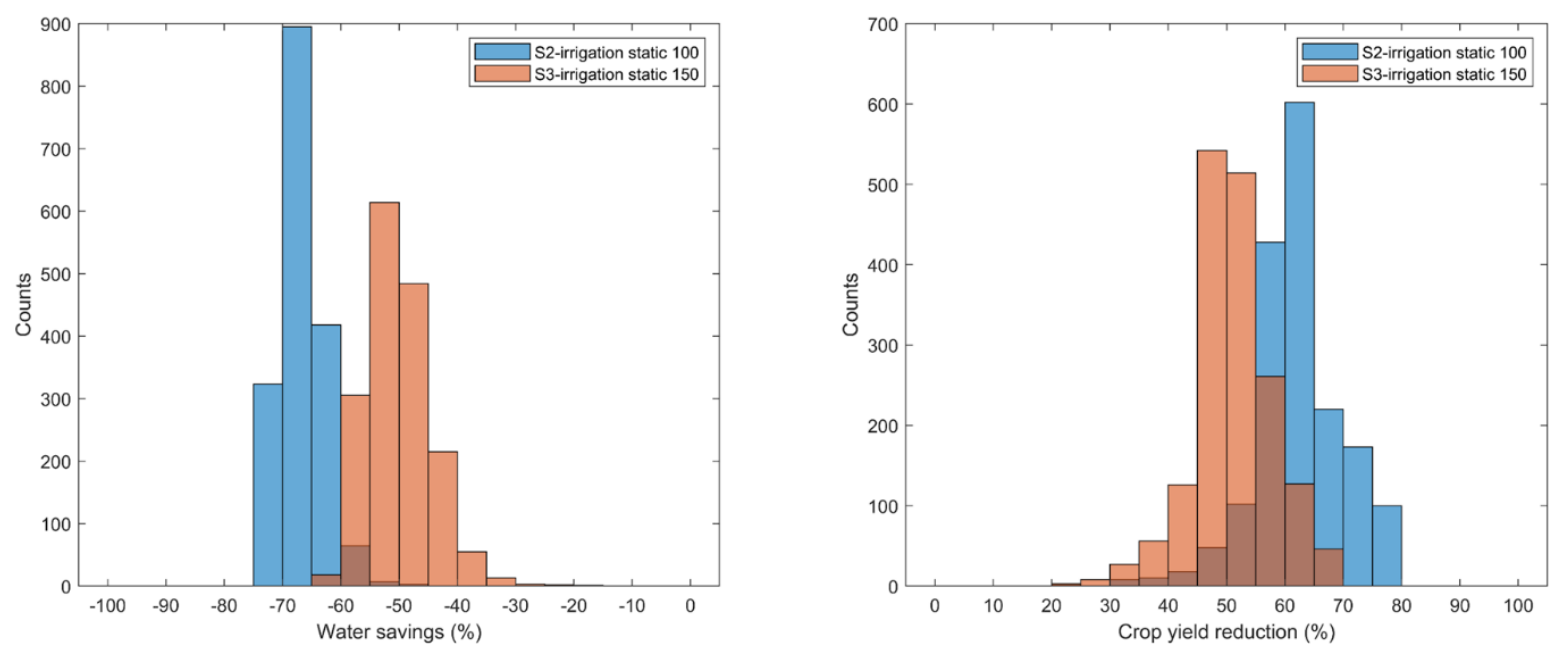

Figure 11: Water savings using the irrigation guidelines from the developed model (scenario S1irrigation ET) versus scenarios S2-irrigation static 100 and S3-irrigation static 150 (left) and crop yield reduction of scenarios S2-irrigation static 100 and S3-irrigation static 150 as compared to S1-irrigation (right) for 2018.
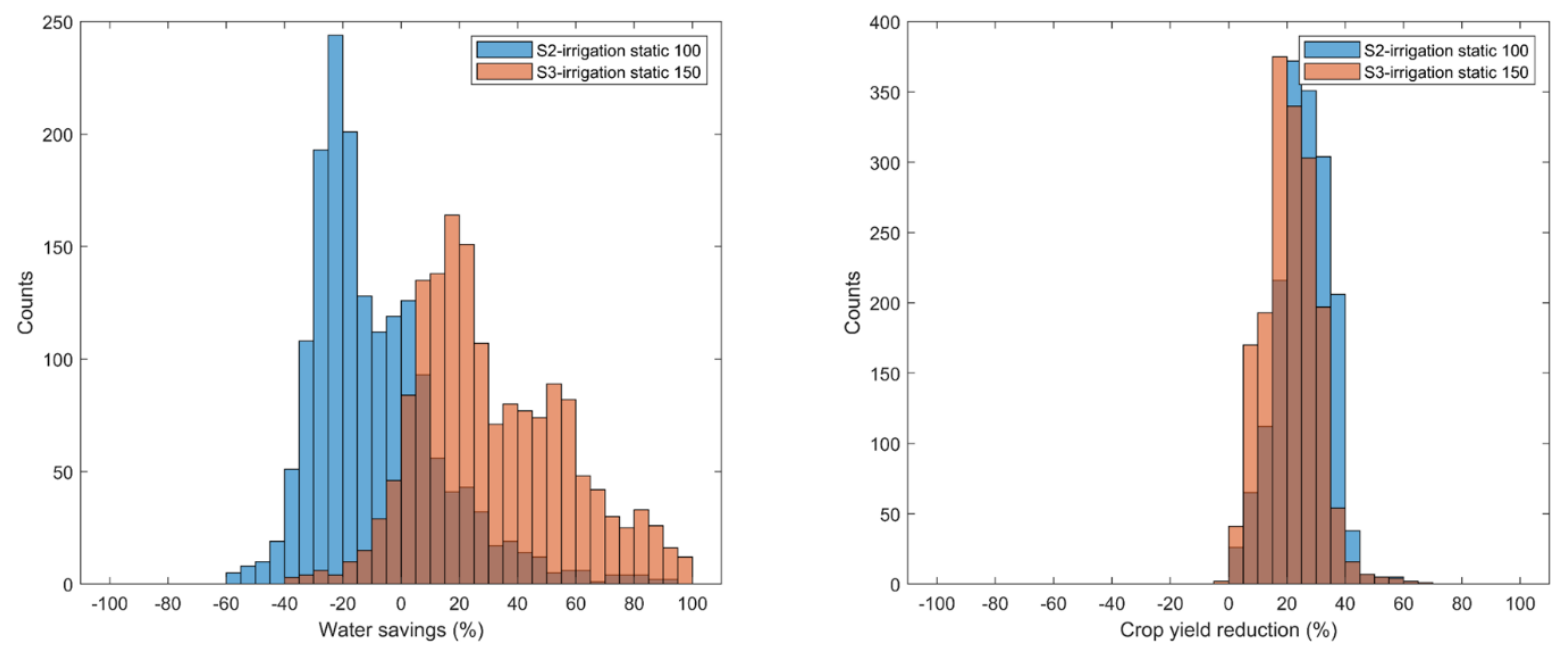

Figure 12: Water savings using the irrigation guidelines from the developed model (scenario S1irrigation ET) versus scenarios S2-irrigation static 100 and S3-irrigation static 150 (left) and crop yield reduction of scenarios S2-irrigation static 100 and S3-irrigation static 150 as compared to S1-irrigation (right) for 2019. 


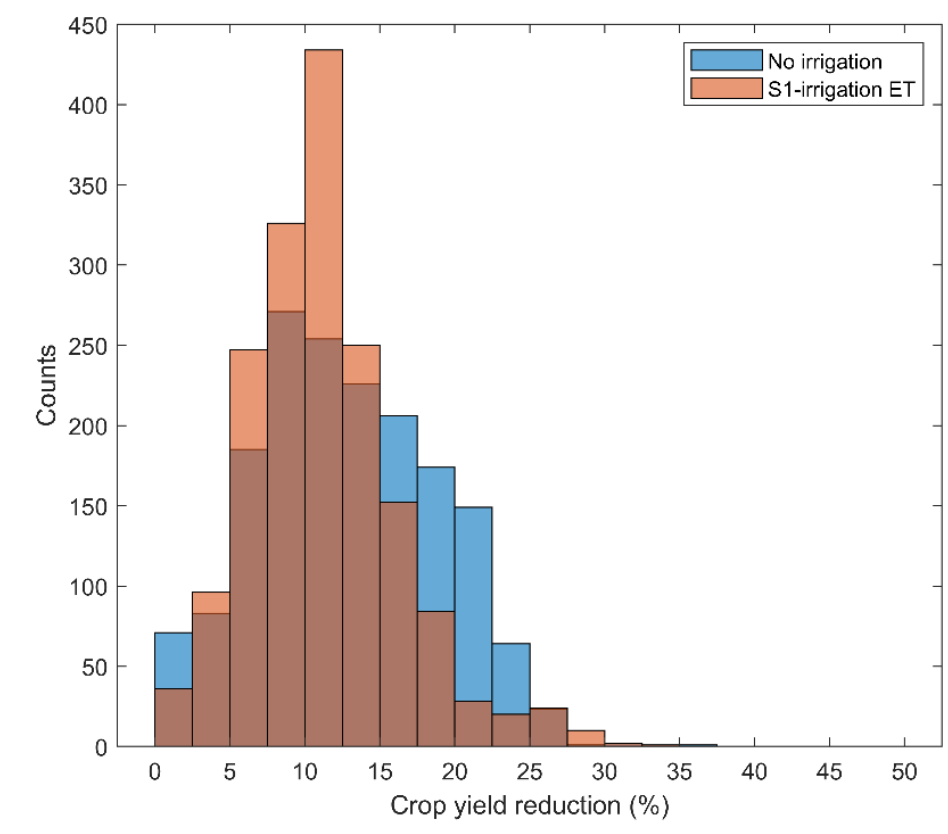

Figure 13: Crop yield reduction due to temperature stress in case of no irrigation and in case of full irrigation for scenario S1-irrigation ET in 2018.

\subsection{Energy consumption and further developments}

The energy consumption in the irrigation sector for different scenarios as defined in Table 4 are depicted in Figures 14 and 15. The scenario S1-energy shows an energy consumption in the order of ten times higher than the best-case scenario (S2-energy). This is due to the combination of efficiencies in the modelling chain, water resources depth, and other parameters (Table 4). While this result might not significantly affect a single farmer due to the current low electricity price in Sweden (Eurostat, 2021a), it might substantially affect the regional energy systems in terms of matching electricity supply and demand. This mismatch at larger scale (i.e., not at a farm level) might lead to a spike in the electricity price due to higher demands that can afterwards affect farmers and in general the entire electricity buyers. Moreover, this is likely to happen during extreme droughts events and or for long terms negative climate changes that typically already put pressure on energy systems, in particular hydropower and thermal energy conversion plants (Riksbanken, 2018). From a WFE nexus perspective, the results in Figures 14 and 15 are important to in a broader energy and water contexts. As mentioned in section 2.2, to better understand the WFE nexus with a more integrated approach, the model presented in this study will be further developed to analyze other key sectors, such as the agriculture, industrial, power, as well as the commercial and residential sectors. The developed the model will be able to study spatiallyexplicit water and energy demands and supplies at high temporal resolution, which will enable the identification of potential energy demand and supply mismatches, especially during extreme events and or using climate change scenarios data. The integration of such model with a hydrological model will also allow to identify potential water supply and demand mismatches and thus perform better allocation of water and natural resources. 

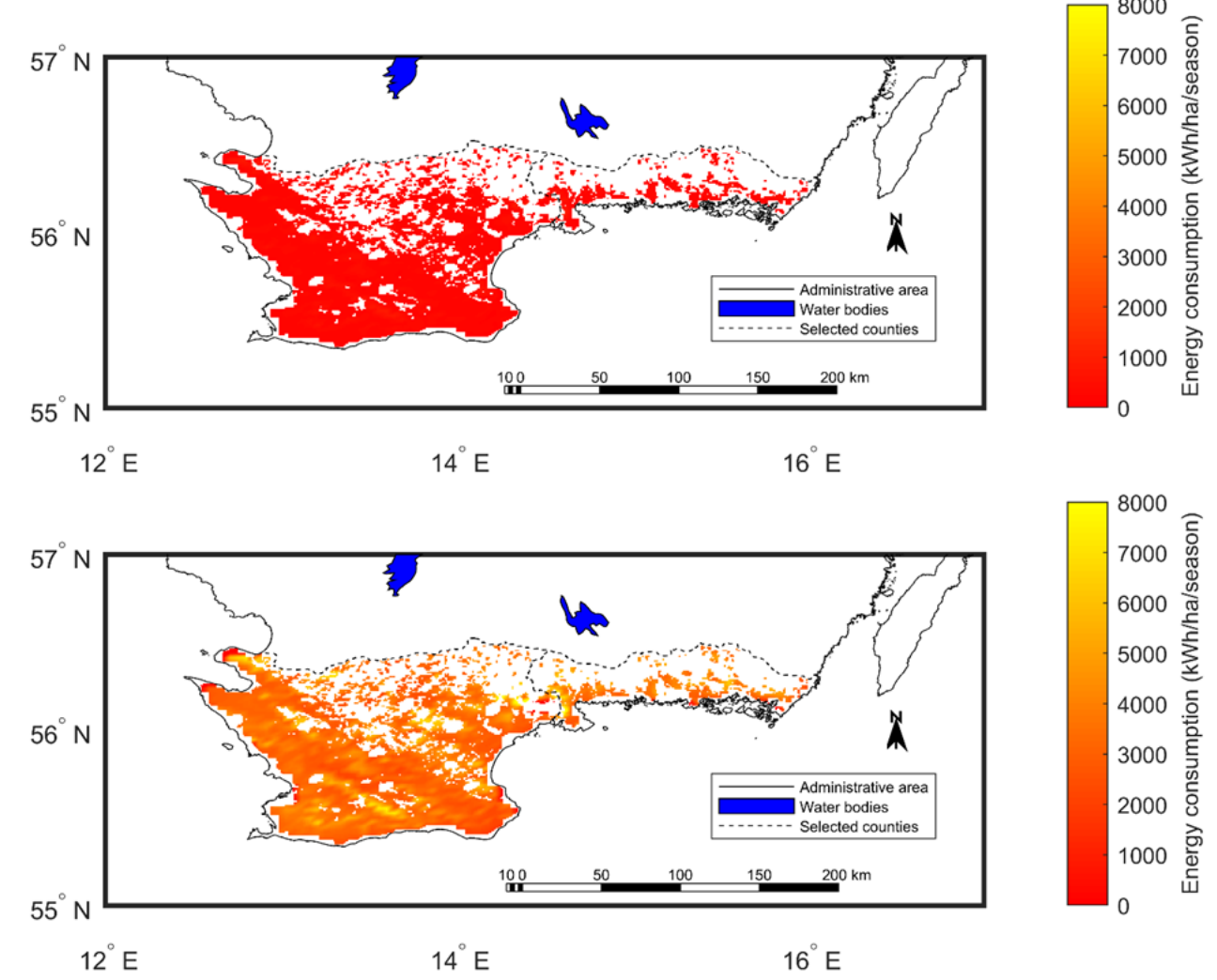

Figure 14: Comparison between energy consumption in the irrigation sector in the investigated worst (S1-energy) (top) and best case (S2-energy) (down) scenarios.

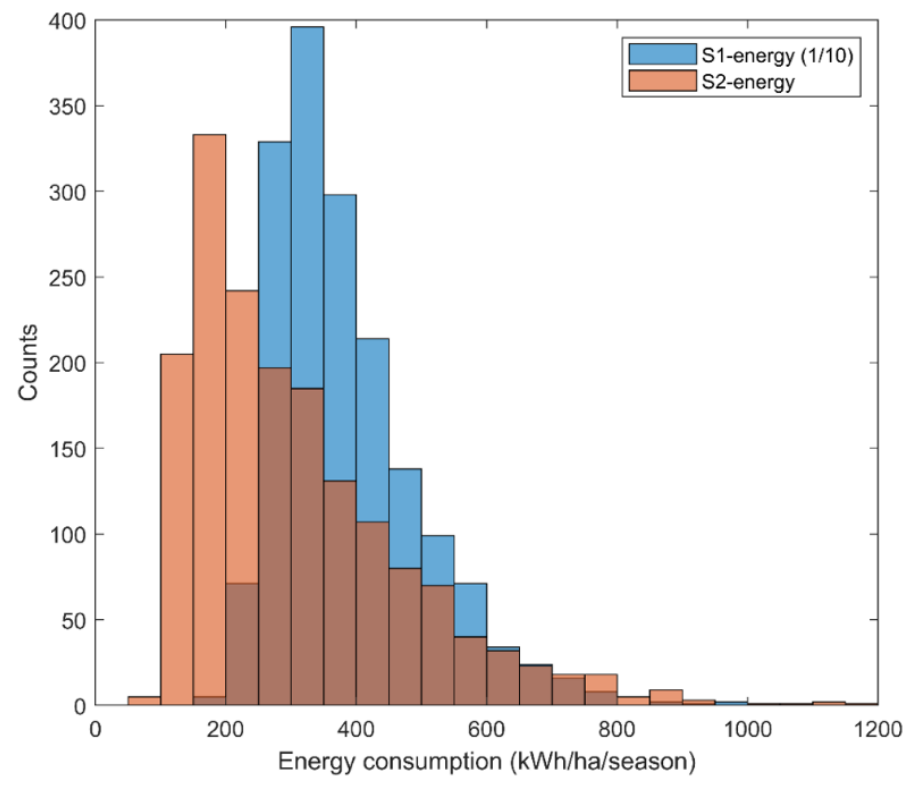

Figure 15: Distribution of the energy consumption in the irrigation sector in the investigated worst (S1-energy) and best (S2-energy) energy scenarios. 


\subsection{The irrigation management service interface}

A screenshot of the irrigation management service interface is provided in Figure 16, where the users can view the daily reference evapotranspiration $E T_{0}$ maps for all of Sweden. Once all the data are retrieved from the server, the maps can be visualized with time dimension by using the time slider. By specifying the field Evapotranspiration cities, the users can also view and download daily-based timeseries of $E T_{0}$ and precipitation data for the selected locations across all the country (Figure 17). The locations possible to retrieve the $E T_{0}$ and precipitation time-series will appear on the map. The data on $E T_{0}$ and precipitation can be used as starting point for more accurate assessment of crop water requirements using the FAO guidelines (Allen et al., 1998). Moreover, by assimilating LAI observation as described in sections 3.2 and 4.1, the current version of the model could be further expanded to specifically cover the most irrigated crops in the country providing timely guidelines for farmers. By integrating $E T_{0}$ maps with maps concerning the irrigation areas and water resources depth and availability, water and energy management agencies managers could have a better view of potential water and energy consumption from the irrigation sector. The developed interface can provide largescale and cost-effective irrigation management services and decision support in both developed and developing countries, especially in those areas with significant water and food security issues.

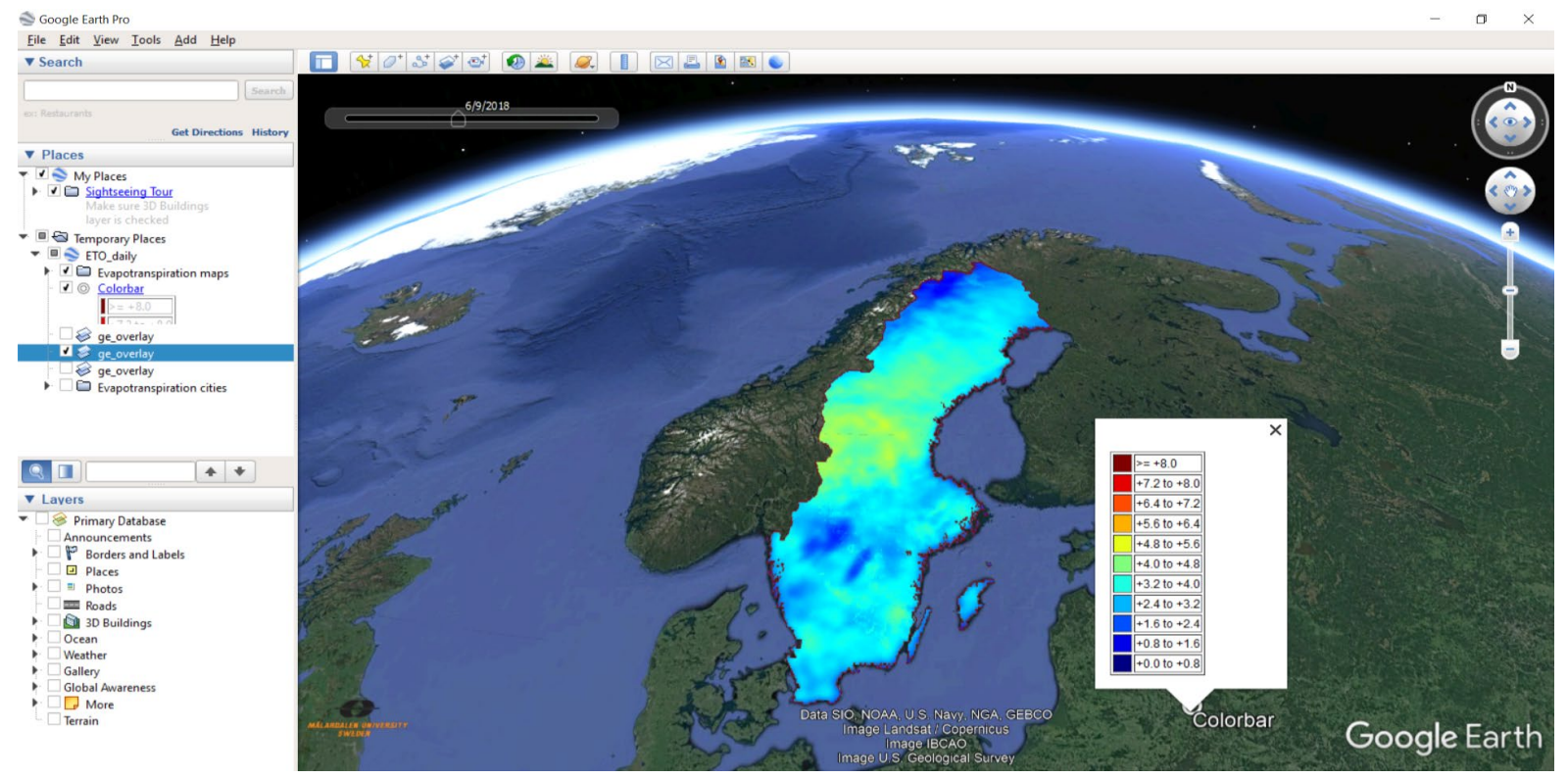

Figure 16: Screenshot of the irrigation management service interface. 


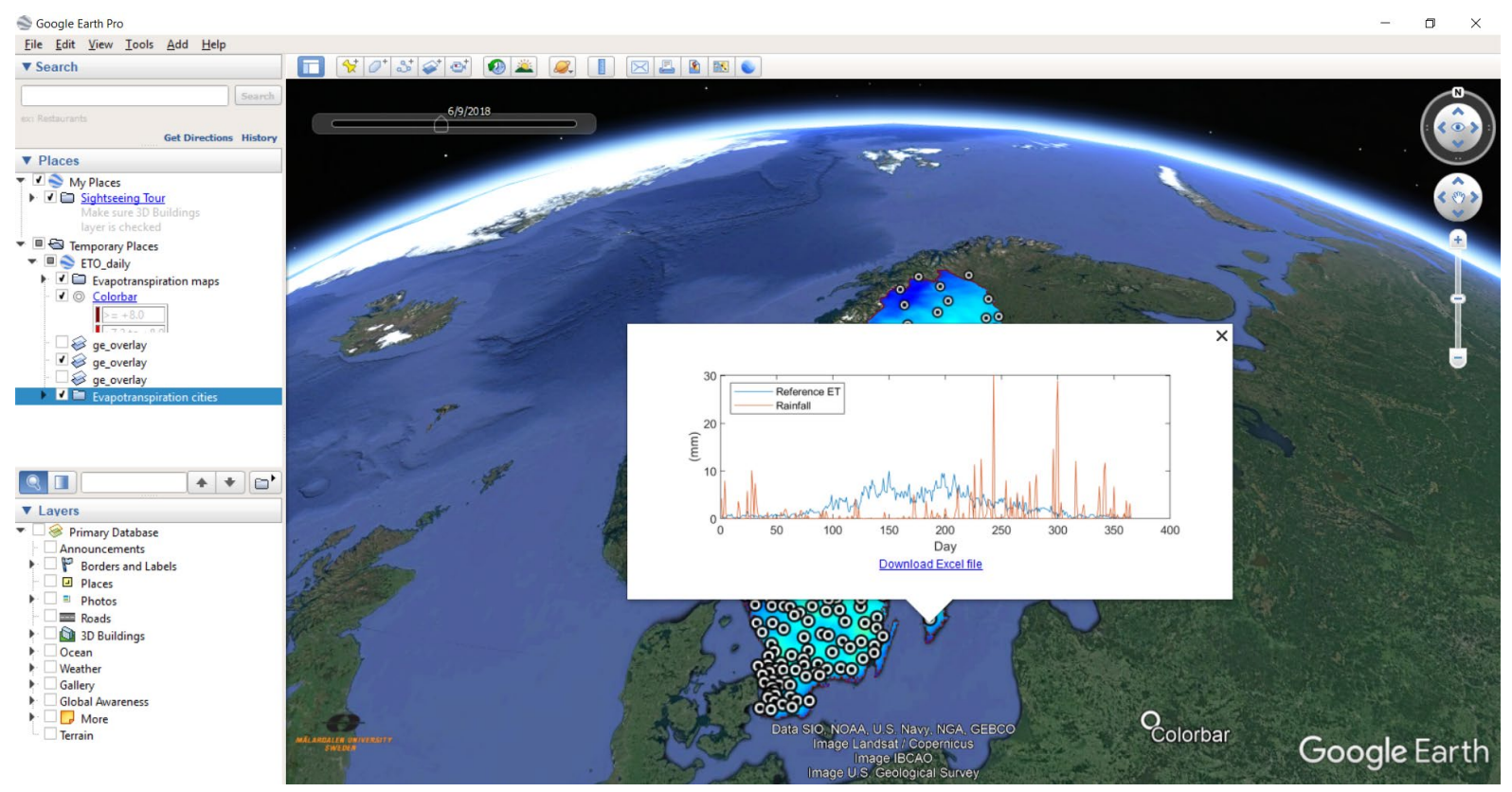

Figure 17: Retrieval of time-series reference evapotranspiration and precipitation for specified locations across Sweden.

\section{Conclusions}

This study aimed to develop an operational water-food-energy nexus system for the irrigation sector in Sweden, focusing on the interrelationships between water and energy requirements for irrigation and corresponding crop yield response. The 2018 drought that severely hit Sweden is used as the case study. The results are compared with a normal year. The main conclusions from this study are the following:

- the use of Penman-Monteith instead of the Hargreaves and Samani equation for estimating the crop reference evapotranspiration shows slightly better results in the modelling chain for estimating the crop yield: $0.11 \mathrm{t} / \mathrm{ha}$ difference at Lanna in 2018. Although the higher performances of Penman-Monteith, it requires significant more input data as compared to Hargreaves and Samani's model. This demonstrates that the implementation of Hargreaves and Samani equation provides a good trade-off between accuracy and complexity for operational service

- by assimilating the leaf area index from Copernicus Global Land Service into the crop model through optimization, the model presents the best results while comparing the simulated crop yield with the measured crop yield at the Lanna ICOS FLUXNET station

- the irrigation water productivity using the developed model shows better results as compared to existing static and non-spatially explicit guidelines both in 2018 and in 2019

- during the drought year 2018, the developed model showed no irrigation water savings as compared to conventional irrigation guidelines. Nevertheless, the conventional irrigation guidelines show crop yield reductions between 20 to $80 \%$ as compared to the crop yield achieved through the irrigation heights generated by the developed model.

- in 2019, most of the water savings ranged between - $60 \%$ (i.e., increased irrigation water volume as compared to static guidelines) to $95 \%$ with crop yield reductions ranging between $-5 \%$ (i.e., crop yield increase) to $70 \%$. Those modelling results align with the previous studies on the implementation of large-scale irrigation management services in the USA

- the modelling result shows a significant reduction in crop yield up to $35 \%$ due to temperature stress as compared to ideal case without temperature stress. This justifies the implementation of 
technologies that can mitigate the negative effects of weather extremes (e.g., drought) and climate changes on the water-food-energy nexus interrelationships.

- The developed platform, based on an open-source package for Google Earth ${ }^{\circledR}$, can be easily implemented to help farmers, and water and energy management agencies to better understand the water, energy, and food nexus and make informed decisions especially during the occurrence of extreme events.

In future studies, the proposed model will be extended to other key sectors, such as the power and industrial sector, to perform optimal allocation of natural resources on large-scale.

\section{Acknowledgments}

The authors acknowledge ICOS for providing the data from the Lanna station to validate the models of crop yield, actual evapotranspiration, and soil moisture. Pietro Elia Campana acknowledges the Future Energy Center internal funding for the projects "Towards An Optimal Irrigation Management System from the Water-Food-Energy Nexus Perspective" and "A Gridded Water-Food-Energy Nexus Management System for Sweden" and the Swedish Energy Agency for the project "Evaluation of the first agrivoltaic system in Sweden". Pietro Elia Campana also thanks the financial support of Almi for the computing facilities. The support received from Mattias Holmquist, coordinator of the biosphere area Blekinge Arkipelag, is sincerely appreciated.

\section{References}

Allen, R. G., Pereira, L. S., Raes, D., \& Smith, M. (1998). Crop evapotranspiration-Guidelines for computing crop water requirements-FAO Irrigation and drainage paper 56. Fao, Rome, 300(9), D05109. Amaducci, S., Yin, X., \& Colauzzi, M. (2018). Agrivoltaic systems to optimise land use for electric energy production. Applied energy, 220, 545-561.

Amjath-Babu, T. S., Sharma, B., Brouwer, R., Rasul, G., Wahid, S. M., Neupane, N., ... \& Sieber, S. (2019). Integrated modelling of the impacts of hydropower projects on the water-food-energy nexus in a transboundary Himalayan river basin. Applied energy, 239, 494-503.

Awal, R., Habibi, H., Fares, A., \& Deb, S. (2020). Estimating reference crop evapotranspiration under limited climate data in West Texas. Journal of Hydrology: Regional Studies, 28, 100677.

Balkovič, J., van der Velde, M., Schmid, E., Skalský, R., Khabarov, N., Obersteiner, M., ... \& Xiong, W. (2013). Pan-European crop modelling with EPIC: Implementation, up-scaling and regional crop yield validation. Agricultural Systems, 120, 61-75.

Barron, J. (2020, June 3). Personal interview.

Barron-Gafford, G. A., Pavao-Zuckerman, M. A., Minor, R. L., Sutter, L. F., Barnett-Moreno, I., Blackett, D. T., ... \& Macknick, J. E. (2019). Agrivoltaics provide mutual benefits across the foodenergy-water nexus in drylands. Nature Sustainability, 2(9), 848-855.

Battilani, A. (2004, November). Fertirrigere V2. 11: a multi-target DSS to manage water and nutrient supply at macrozone level. In IX International Symposium on the Processing Tomato 724 (pp. 111-118). Bazilian, M., Rogner, H., Howells, M., Hermann, S., Arent, D., Gielen, D., ... \& Yumkella, K. K. (2011). Considering the energy, water and food nexus: Towards an integrated modelling approach. Energy policy, 39(12), 7896-7906.

Belusic, D., Berg, P., Bozhinova, D., Bärring, L., Doescher, R., Eronn, A., ... Strandberg, G. (2019). Climate Extremes for Sweden. https://doi.org/10.17200/Climate_Extremes_Sweden

Bergström, U., \& Barkefors, C. (2004). Irrigation in dose assessments models (No. SKB-R-04-26). Swedish Nuclear Fuel and Waste Management Co.

Bioenergy International. Available at: https://bioenergyinternational.com/feedstock/swedens-2018crop-harvest-worst-since-the-late-1950s. Accessed 24 ${ }^{\text {th }}$ August 2020. 
Bos, M. G. (1985). Summary of ICID definitions on irrigation efficiency.

Brundell, P., Kanlén, F., \& Westöö, A. K. (2008). Water use for irrigation. Report on Grant Agreement, (71301.2006), 002-2006.

Burrow, A., Newman, A., \& Bazilian, M. (2019). Reservoir Design and Operation for the Food-EnergyWater Nexus. Current Sustainable/Renewable Energy Reports, 6(3), 71-89.

Campana, P. E., Li, H., Zhang, J., Zhang, R., Liu, J., \& Yan, J. (2015). Economic optimization of photovoltaic water pumping systems for irrigation. Energy Conversion and Management, 95, 32-41.

Campana, P. E., Zhang, J., Yao, T., Andersson, S., Landelius, T., Melton, F., \& Yan, J. (2018). Managing agricultural drought in Sweden using a novel spatially-explicit model from the perspective of water-food-energy nexus. Journal of cleaner production, 197, 1382-1393.

Castell-Perez, E., Gomes, C., Tahtouh, J., Moreira, R., McLamore, E. S., \& Knowles, H. S. (2017). Food processing and waste within the nexus framework. Current Sustainable/Renewable Energy Reports, 4(3), 99-108.

Copernicus Global Land Service. Available at: https://land.copernicus.eu/global/products/lai. Accessed $17^{\text {th }}$ October 2020.

Daccache, A., Ciurana, J. S., Diaz, J. R., \& Knox, J. W. (2014). Water and energy footprint of irrigated agriculture in the Mediterranean region. Environmental Research Letters, 9(12), 124014.

Dai, J., Wu, S., Han, G., Weinberg, J., Xie, X., Wu, X., ... \& Yang, Q. (2018). Water-energy nexus: A review of methods and tools for macro-assessment. Applied energy, 210, 393-408.

DeJonge, K. C., Ascough Ii, J. C., Andales, A. A., Hansen, N. C., Garcia, L. A., \& Arabi, M. (2012). Improving evapotranspiration simulations in the CERES-Maize model under limited irrigation. Agricultural Water Management, 115, 92-103.

Destouni, G., Jaramillo, F., \& Prieto, C. (2013). Hydroclimatic shifts driven by human water use for food and energy production. Nature Climate Change, 3(3), 213-217.

Dominic, W. (2011). Water Security: The Water-Food-Energy-Climate Nexus: The World Economic Forum Water Initiative.

Dutta, D., Vaze, J., Kim, S., Hughes, J., Yang, A., Teng, J., \& Lerat, J. (2017). Development and application of a large scale river system model for National Water Accounting in Australia. Journal of Hydrology, 547, 124-142.

Eftelioglu, E., Jiang, Z., Ali, R., \& Shekhar, S. (2016). Spatial computing perspective on food energy and water nexus. Journal of Environmental Studies and Sciences, 6(1), 62-76.

Ehmke, T. (2014). Subsurface drip irrigation: Battling drought, water restrictions, and declining groundwater. Crops \& Soils, 47(4), 4-10.

Endo, A., Yamada, M., Miyashita, Y., Sugimoto, R., Ishii, A., Nishijima, J., \& Kumazawa, T. (2019). Dynamics of Water-Energy-Food Nexus Methodology, Methods, and Tools. Current Opinion in Environmental Science \& Health.

Espinosa-Tasón, J., Berbel, J., \& Gutiérrez-Martín, C. (2020). Energized water: Evolution of waterenergy nexus in the Spanish irrigated agriculture, 1950-2017. Agricultural Water Management, 233, 106073.

Eurostat. (2021) Available at: https://ec.europa.eu/eurostat/statisticsexplained/index.php/Electricity_price_statistics\#Electricity_prices_for_non-household_consumers.

Accessed $31^{\text {st }}$ January 2021.

Fan, Y., Li, H., \& Miguez-Macho, G. (2013). Global patterns of groundwater table depth. Science, 339(6122), 940-943.

Foltescu, V. L. (2000). Prediction of crop yield in Sweden based on mesoscale meteorological analysis. Meteorological Applications: A journal of forecasting, practical applications, training techniques and modelling, 7(4), 313-321.]

Food and Agriculture Organization (2017). The Future of Food and Agriculture: Trends and Challenges. 
Food and Agriculture Organization. AQUASTAT: Global map of irrigation areas. (2016)

Frankowska, A., Jeswani, H. K., \& Azapagic, A. (2019). Environmental sustainability issues in the foodenergy-water nexus in the UK vegetables sector: Energy and water consumption. Energy Procedia, 161, 150-156.

FutureWater. Available at: https://www.futurewater.eu/projects/irrigation-management-romania/. Accessed $30^{\text {th }}$ January 2020

Galindo, J., Torok, S., Salguero, F., de Campos, S., Romera, J., \& Puig, V. (2017). Optimal Management of Water and Energy in Irrigation Systems: Application to the Bardenas Canal. IFAC-PapersOnLine, 50(1), 6613-6618.

Gallardo et al. (2020). Decision support systems and models for aiding irrigation and nutrient management of vegetable crops. Agricultural Water Management, 106209

Global Soil Data Task Group. 2000. Global Gridded Surfaces of Selected Soil Characteristics (IGBPDIS).

Google Earth Pro®. Available at: https://www.google.com/earth/versions/. Accessed $9^{\text {th }}$ January 2021

Gorelick, N., Hancher, M., Dixon, M., Ilyushchenko, S., Thau, D. and Moore, R. (2017). Google Earth Engine: Planetary-scale geospatial analysis for everyone. Remote sensing of Environment, 202, pp.1827.

Government Offices of Sweden, The agricultural sector and the drought, https://www.government.se/articles/2018/08/the-agricultural-sector-and-the-drought/. Accessed $24^{\text {th }}$ May 2020.

Grusson, Y., Wesström, I., \& Joel, A. (2021). Impact of climate change on Swedish agriculture: Growing season rain deficit and irrigation need. Agricultural Water Management, 251, 106858.

Gu, L., Hu, Z., Yao, J., \& Sun, G. (2017). Actual and reference evapotranspiration in a cornfield in the zhangye oasis, northwestern China. Water, 9(7), 499.

Hargreaves, G. H., \& Samani, Z. A. (1982). Estimating potential evapotranspiration. Journal of the irrigation and Drainage Division, 108(3), 225-230.

Hanson, B., \& Putnam, D. (2000, December). Can alfalfa be produced with less water. In Proc. 29th Natl. Alfalfa Symp. and 30th California Alfalfa Symp (pp. 00-043). Davis, CA: Univ. CA, Dept. of Agronomy and Range Science.

Hughes, J., Mainuddin, M., Lerat, J., Dutta, D., \& Kim, S. S. H. (2013, December). An irrigation model for use in river systems modelling. In Proceedings of the 20th International Congress on Modelling and Simulation, Adelaide, Australia (pp. 1-6).

ICOS. (2019). Ecosystem Thematic Centre and Lanna: Drought-2018 ecosystem eddy covariance flux product from Lanna, doi:10.18160/GPS8-BGNW.

ICOS. (2021). Available at: https://www.icos-sweden.se/lanna

Irmak, S., Odhiambo, L. O., Kranz, W. L., \& Eisenhauer, D. E. (2011). Irrigation efficiency and uniformity, and crop water use efficiency.

IRMA_SYSTEM. (2021). Available at: https://arta.interregir2ma.eu/.

Jaramillo, F., Prieto, C., Lyon, S. W., \& Destouni, G. (2013). Multimethod assessment of evapotranspiration shifts due to non-irrigated agricultural development in Sweden. Journal of Hydrology, 484, 55-62.

Jin, X., Kumar, L., Li, Z., Feng, H., Xu, X., Yang, G., \& Wang, J. (2018). A review of data assimilation of remote sensing and crop models. European Journal of Agronomy, 92, 141-152.

Johnson, L. F., Cahn, M., Martin, F., Melton, F., Benzen, S., Farrara, B., \& Post, K. (2016). Evapotranspiration-based irrigation scheduling of head lettuce and broccoli. HortScience, 51(7), 935940. 
Jungqvist, G., Oni, S. K., Teutschbein, C., \& Futter, M. N. (2014). Effect of climate change on soil temperature in Swedish boreal forests. PloS one, 9(4).

Kaddoura, S., \& El Khatib, S. (2017). Review of water-energy-food Nexus tools to improve the Nexus modelling approach for integrated policy making. Environmental Science \& Policy, 77, 114-121

Kibler, K. M., Reinhart, D., Hawkins, C., Motlagh, A. M., \& Wright, J. (2018). Food waste and the food-energy-water nexus: a review of food waste management alternatives. Waste management, 74, 5262.

Ko, J., \& Piccinni, G. (2009). Corn yield responses under crop evapotranspiration-based irrigation management. Agricultural water management, 96(5), 799-808.

Krikken, F., Lehner, F., Haustein, K., Drobyshev, I., \& van Oldenborgh, G. J. (2019). Attribution of the role of climate change in the forest fires in Sweden 2018. Natural Hazards and Earth System Sciences Discussions, 1-24.

Lawford, R. G. (2019). A design for a data and information service to address the knowledge needs of the Water-Energy-Food (WEF) Nexus and strategies to facilitate its implementation. Frontiers in Environmental Science, 7, 56.

Lima, F. A., Martínez-Romero, A., Tarjuelo, J. M., \& Córcoles, J. I. (2018). Model for management of an on-demand irrigation network based on irrigation scheduling of crops to minimize energy use (Part I): Model Development. Agricultural water management, 210, 49-58.

Lindenmayer, R. B., Hansen, N. C., Brummer, J., \& Pritchett, J. G. (2011). Deficit irrigation of alfalfa for water-savings in the Great Plains and Intermountain West: A review and analysis of the literature. Agronomy Journal, 103(1), 45-50.

Liu J., Yang H., Cudennec C., Gain A.K., Hoff H., Lawford R., Qi J., de Strasser L., Yillia P.T., Zheng C., 2017. Panta Rhei Opinions: Challenges in operationalizing the water-energy-food nexus. Hydrological Sciences Journal 62 (11): 1714-1720

Mahlknecht, J., González-Bravo, R., \& Loge, F. J. (2020). Water-energy-food security: A Nexus perspective of the current situation in Latin America and the Caribbean. Energy, 194, 116824.

Mahmoud, S. H., \& Gan, T. Y. (2019). Irrigation water management in arid regions of Middle East: Assessing spatio-temporal variation of actual evapotranspiration through remote sensing techniques and meteorological data. Agricultural Water Management, 212, 35-47.

Malamos, N., Tsirogiannis, I. L., Christofides, A., Anastasiadis, S., \& Vanino, S. (2015, September). Main Features and Application of a Web-based Irrigation Management Tool for the Plain of Arta. In HAICTA (pp. 174-185).

Mannini, P., Genovesi, R., \& Letterio, T. (2013). IRRINET: large scale DSS application for on-farm irrigation scheduling. Procedia Environmental Sciences, 19(0), 823-829.

Martin-Candilejo, A., Santillán, D., \& Garrote, L. (2020). Pump Efficiency Analysis for Proper Energy Assessment in Optimization of Water Supply Systems. Water, 12(1), 132.

McCarl, B. A., Yang, Y., Srinivasan, R., Pistikopoulos, E. N., \& Mohtar, R. H. (2017). Data for WEF nexus analysis: A review of issues. Current Sustainable/Renewable Energy Reports, 4(3), 137-143.

Melton, F.S., Johnson, L.F., Lund, C.P., Pierce, L.L., Michaelis, A.R., Hiatt, S.H., Guzman, A., Adhikari, D.D., Purdy, A.J., Rosevelt, C. and Votava, P. (2012). Satellite irrigation management support with the terrestrial observation and prediction system: a framework for integration of satellite and surface observations to support improvements in agricultural water resource management. IEEE Journal of Selected Topics in Applied Earth Observations and Remote Sensing, 5(6), 1709-1721.

Moorhead, J. E., Marek, G. W., Gowda, P. H., Lin, X., Colaizzi, P. D., Evett, S. R., \& Kutikoff, S. (2019). Evaluation of Evapotranspiration from Eddy Covariance Using Large Weighing Lysimeters. Agronomy, 9(2), 99.

Myrbeck, Å. (1998). Swedish agricultural and horticultural crops. PM-Kemikalieinspektionen-KEMI (Sweden). 
Novelli, F., Spiegel, H., Sandén, T., \& Vuolo, F. (2019). Assimilation of sentinel-2 leaf area index data into a physically-based crop growth model for yield estimation. Agronomy, 9(5), 255

Ochoa-Sánchez, A., Crespo, P., Carrillo-Rojas, G., Sucozhañay, A., \& Célleri, R. (2019). Actual evapotranspiration in the high Andean grasslands: a comparison of measurement and estimation methods. Frontiers in Earth Science, 7, 55.

OpenET. Available at: https://openetdata.org/. Accessed $31^{\text {st }}$ January 2021.

Pereira, L.S., Paredes, P., Melton, F., Johnson, L., Wang, T., López-Urrea, R., Cancela, J.J. and Allen, R.G. (2020). Prediction of crop coefficients from fraction of ground cover and height. Background and validation using ground and remote sensing data. Agricultural Water Management, 241, p.106197.

Phocaides, A. (2000). Technical handbook on pressurized irrigation techniques. FAO, Rome, 372.

Renew Economy. Available at: https://reneweconomy.com.au/nuclear-power-takes-a-hit-as-europeanheatwave-rolls-on-87477/. Accessed $24^{\text {th }}$ May 2020.

Riksbanken (2018). Avialble at: https://www.riksbank.se/globalassets/media/rapporter/ppr/fordjupningar/engelska/2018/small-effectson-production-and-inflation-of-the-summers-drought-and-forest-fires-article-in-monetary-policyreport-september-2018.pdf. Accessed: $31^{\text {st January } 2021 .}$

Rockström, J., Steffen, W., Noone, K., Persson, Å., Chapin, F. S., Lambin, E. F., ... \& Foley, J. A. (2009). A safe operating space for humanity. nature, 461(7263), 472-475.

Scott Lee Davis (2020). Google Earth

Toolbox (https://www.mathworks.com/matlabcentral/fileexchange/12954-google-earth-toolbox),

MATLAB Central File Exchange. Retrieved August 6, 2020.

Shannak, S., Mabrey, D., \& Vittorio, M. (2018). Moving from theory to practice in the water-energyfood nexus: an evaluation of existing models and frameworks. Water-Energy Nexus, 1(1), 17-25.

SMHI. (2020 a). Available at: https://www.smhi.se/klimat/klimatet-da-och-nu/manadens-vader-ochvatten-sverige/manadens-vader-i-sverige/juli-2018-langvarig-hetta-och-svara-skogsbrander-

1.137248. Accessed $11^{\text {th }}$ April 2021.

SMHI, Analysmodell MESAN. (2020 b). Available at: https://www.smhi.se/data/oppnadata/meteorologiska-data/analysmodell-mesan-1.30445. Accessed 23rd August 2020

SMHI. (2020c). HYPE model documentation. Available at: http://www.smhi.net/hype/wiki/doku.php?id=start:hype_model_description:hype_human_water\#irriga tion. Accessed $17^{\text {th }}$ October 2020.

SPEI Global Drought Monitor, Available at: https://spei.csic.es/map/maps.html\#months $=0 \#$ month=11\#year=1958. Accessed $24^{\text {th }}$ May 2020.

Sperling, J. B., \& Berke, P. R. (2017). Urban nexus science for future cities: Focus on the energy-waterfood-X nexus. Current Sustainable/Renewable Energy Reports, 4(3), 173-179.

Statistic Sweden. (2018) Standard yields for yield survey districts, counties and the whole country in 2018. Available at: https://www.scb.se/publication/35137. Accessed $31^{\text {st }}$ January 2021

Statistic Sweden. (2021). Available at: http://www.statistikdatabasen.scb.se/pxweb/en/ssd/START_MI_MI0902_MI0902E/VattenAnvJor d/. Accessed: $31^{\text {st }}$ January 2021

Stepanovic, S., Rudnick, D., \& Kruger, G. Impact of maize hybrid selection on water productivity under deficit irrigation in semiarid western Nebraska. Agricultural Water Management, 244, 106610.

STRÅNG. Available at: http://strang.smhi.se/. Accessed 23 ${ }^{\text {rd }}$ August 2020

SWEDIMS. Available at: www.swedims.se. Accessed $9^{\text {th }}$ January 2021

Swedish Board of Agriculture. (2007). Bevattning och växtnäringsutnyttjande. Available at: https://webbutiken.jordbruksverket.se/sv/artiklar/bevattning-och-vaxtnaringsutnyttjande.html.

Accessed 17 $7^{\text {th }}$ October 2020 (in Swedish) 
Swedish Board of Agriculture. Available at: https://jordbruksverket.se/e-tjanster-databaser-och-appar/etjanster-och-databaser-stod/kartor-och-gis. Accessed 24 ${ }^{\text {th }}$ May 2020.

The Local. Available at: www.thelocal.se/tag/drought. Accessed $24^{\text {th }}$ May 2020.

USDA NRCS. (1997). Irrigation guide. National Engineering Handbook, 452. Available at: http://www.nrcs.usda.gov/Internet/FSE_DOCUMENTS/nrcs141p2_017641.pdf.

Wagner, M. P., Slawig, T., Taravat, A., \& Oppelt, N. (2020). Remote Sensing Data Assimilation in Dynamic Crop Models Using Particle Swarm Optimization. ISPRS International Journal of GeoInformation, 9(2), 105.

Wang, W., Cui, Y., Luo, Y., Li, Z., \& Tan, J. (2019). Web-based decision support system for canal irrigation management. Computers and Electronics in Agriculture, 161, 312-321.

Weslien, P. (2020, June 1). Personal interview

Williams, J.R., Jones, C.A., Kiniry, J.R., Spanel, D.A. The EPIC crop growth model. Transactions of the ASAE 32, (1989) 497-511

Wivstad, M., Eckersten, H., Holstein, F., Johansson, S., \& Verwijst, T. (2009). Strategic analysis of Swedish agriculture. Swedish University of Agricultural Sciences, Department of Economics.

Zhai, H., \& Rubin, E. S. (2015). Water impacts of a low-carbon electric power future: assessment methodology and status. Current Sustainable/Renewable Energy Reports, 2(1), 1-9.

Zhang, C., Zhang, M., \& Sun, X. (2012). Henan zhaokou irrigation management system design based on flex viewer. Procedia Engineering, 28, 723-728

Zhang, J., Campana, P. E., Yao, T., Zhang, Y., Lundblad, A., Melton, F., \& Yan, J. (2018). The waterfood-energy nexus optimization approach to combat agricultural drought: a case study in the United States. Applied Energy, 227, 449-464.

Zhang, Y., Song, C., Sun, G., Band, L. E., McNulty, S., Noormets, A., ... \& Zhang, Z. (2016). Development of a coupled carbon and water model for estimating global gross primary productivity and evapotranspiration based on eddy flux and remote sensing data. Agricultural and forest meteorology, 223, 116-131.

Zotarelli, L., Dukes, M. D., Romero, C. C., Migliaccio, K. W., \& Morgan, K. T. (2010). Step by step calculation of the Penman-Monteith Evapotranspiration (FAO-56 Method). Institute of Food and Agricultural Sciences. University of Florida. 